REVIEW ARTICLE

\title{
Green Synthesis of Pyrrole Derivatives
}

\author{
Omar Miguel Portilla Zúñiga a, Ángel Gabriel Sathicqa ${ }^{a}$ José Jobanny Martínez Zambrano ${ }^{b}$ and \\ Gustavo Pablo Romanelli ${ }^{\mathrm{a}, \mathrm{c}, *}$
}

\begin{abstract}
${ }^{a}$ Centro de Investigación y Desarrollo en Ciencias Aplicadas “Dr. Jorge J. Ronco" (CINDECA-CCT-CONICET), Universidad Nacional de La Plata, La Plata, Argentina; ${ }^{b}$ Escuela de Química, Universidad Pedagógica y Tecnológica de Colombia, 15000 Tunja, Colombia; ${ }^{c}$ CISAV. Cátedra de Química Orgánica, Facultad de Ciencias Agrarias y Forestales, Universidad Nacional de La Plata. Calles 60 y 119 s/n, B1904AAN La Plata, Argentina
\end{abstract}

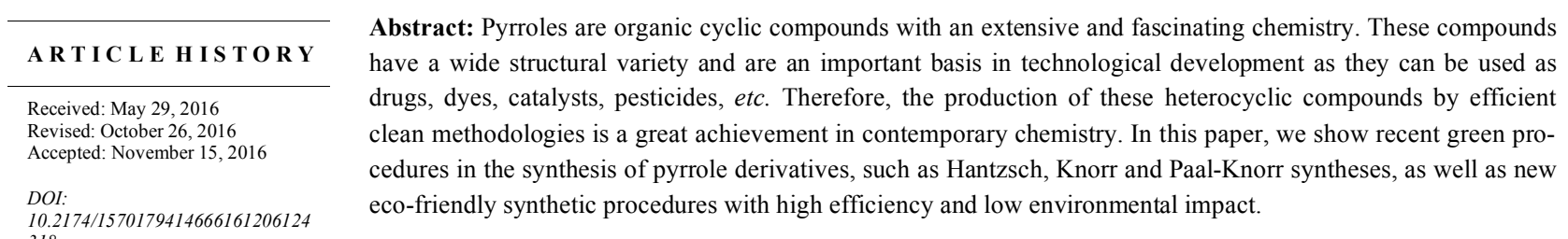

Keywords: Pyrrole, green synthesis, heterocyclic compounds, Hantzsch synthesis, Knorr synthesis, Paal-Knorr synthesis.

\section{INTRODUCTION}

The pyrrole core (1) is widely distributed in nature as the main structure of important molecules such as porphyrins and porphyrin analogues: hemoglobin, chlorophylls, vitamin B12, cytochromes, chlorine, bacteriochlorine, etc. [1] It is also a structural part of different secondary metabolites that have been used in therapeutic drugs [2].

The pyrrole derivatives and analogues have interesting biological activities, such as virus inhibition and specialized inhibition of HIV virus [3], hepatoprotective, antimycotic, antibacterial [4], cholesterol-lowering [5], antipsychotic, antihypertensive, anticarcinogen, antimalarial and anticonvulsant activity [6]. These compounds have an important role in other areas of technological advancement, being used in sensor development, semiconductor synthesis [7], catalysts [8], corrosion inhibitors [9], preservatives [10], luminescence chemistry [11], and spectrochemical analysis [12].

Pyrrole has an aromatic structure with five members, including a nitrogen atom. Compared with other heterocyclic compounds such as pyridine, where the hydrogen atom is not bonded to nitrogen, the pyrrole is a weakest base because the lone pair in the nitrogen contributes to the aromaticity in the structure.

Pyrroles are unstable toward mineral acids and are protonated in the 2-position. The resulting cation polymerizes easily produce pyrrole resins. The common reactions in pyrroles are electrophilic substitutions in 2, 5-position [1].

Pyrroles are obtained by three classical condensation methods: Hantzsch reaction [13], Knorr and Paal-Knorr reactions [14]. Other pyrrole synthesis methods include multicomponent, addition, anne-

*Address correspondence to this author at the Centro de Investigación y Desarrollo en Ciencias Aplicadas "Dr. Jorge J. Ronco" (CINDECA-CCT-CONICET), Universidad Nacional de La Plata, Calle 47 N 257, B1900AJK. La Plata, Argentina;

E-mail: gpr@quimica.unlp.edu.ar lation and Wittig reactions [15]. However, these processes have disadvantages such as the long reaction time, the use of toxic and volatile solvents, low yields, complex purification methods, and the need of high temperature for the occurrence of some reactions [16].

Due to the diverse applications of pyrroles, there is a constant search for environmentally compatible processes for their preparation following the principles of Green Chemistry, i.e., cleaner, efficient and safe processes. Within this framework, a wide variety of catalysts and sustainable methodologies have been developed, such as the use of microwave and ultrasound activation techniques [17], and the replacement of conventional solvents with green solvents such as ethanol, water and ionic liquids or processes performed under solvent-free conditions [18]. This paper reports the latest results in pyrrole synthesis that aims to make the common reactions more eco-friendly for the preparation of these heterocyclic compounds using green methodologies.

\section{SYNTHETHIC METHODS}

\subsection{Knorr Pyrrole Synthesis}

This synthetic method involves the condensation of aminoketone (2) and an $\alpha$-carbonyl compound (3), typically with active methylene groups such as a $\beta$-ketoester. The reaction proceeds with a heat treatment under acidic conditions to obtain tetra- and $\mathrm{N}-\mathrm{H}$ substituted pyrroles (4) usually using acetic acid as solvent (Scheme 2).

Due to the fact that $\alpha$-amino ketones have a tendency to selfcondense, it is preferred to generate them in situ from the corresponding nitrosoketones. The formation of the $\alpha$-nitrosoketone can be easily developed using $\mathrm{HNO}_{2}$ on a carbonyl compound, and subsequently, in the presence of a reducing agent (generally $\mathrm{Zn}$ dust), the $\alpha$-aminoketone (2) is produced. The $N$-substituted pyrroles (5) can be synthesized from secondary $\alpha$-amino ketones and when unsymmetrical ketones are used regioselectively, the larger substituent is located in the $\mathrm{C} 4$ ring. The reaction mechanism involves the condensation of amine with the $\alpha$-carbonyl compound to 


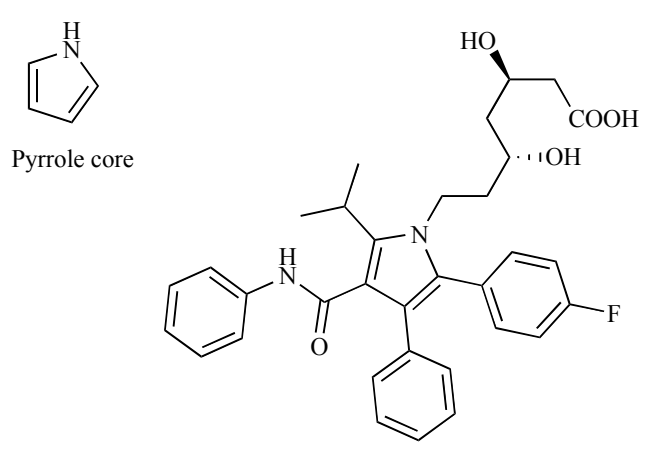

Atrovastatin

(Synthetic hypolipemiant)

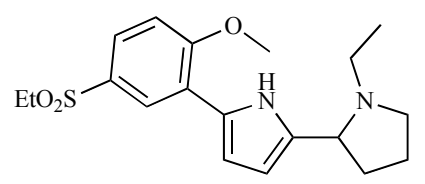

2-(1-ethylpyrrolidin-2-yl)-5-(5-(ethylsulfonyl)-2methoxyphenyl)- $1 H$-pyrrole

(Synthetic antipsychotic)<smiles>O=[N+]([O-])c1c(Cl)cccc1-c1c[nH]cc1Cl</smiles>

Pyrrolnitrin

(Natural antifungal and antibiotic)

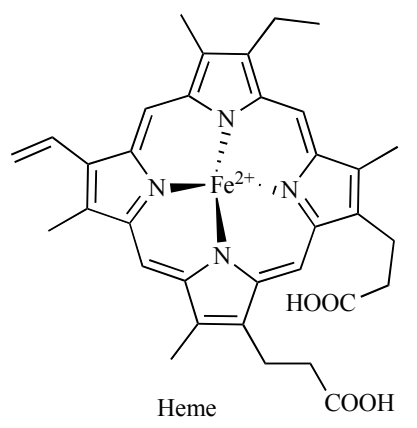

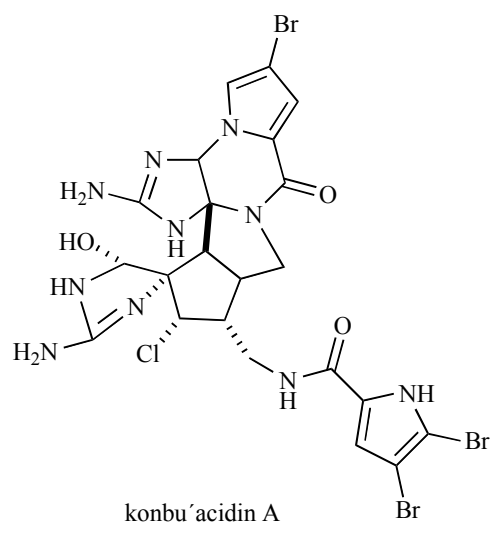

(Cyclin-dependent kinase 4 inhibitor isolated from Hymeniacidon sp.)

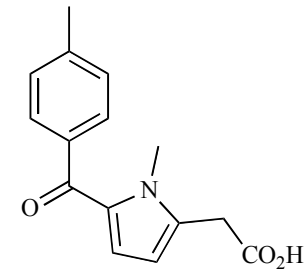

Tolmetin

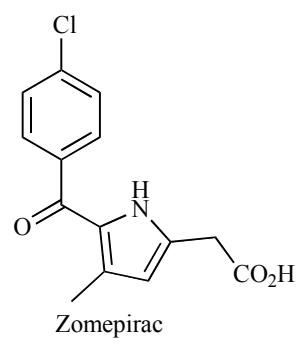<smiles>O=C(c1ccccc1)c1ccc2n1CCC2C(=O)O</smiles>

Ketorolac

(Synthetic analgesic and anti-inflammatory compounds)

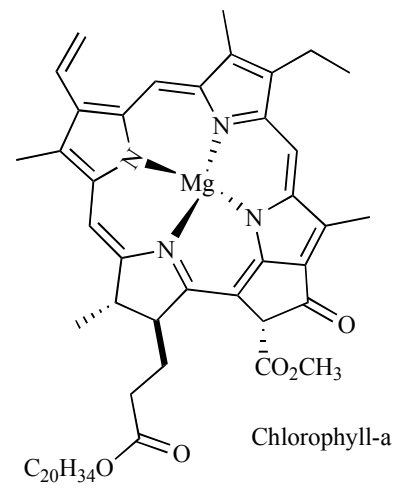

(Biological supramolecular pyrrole derivatives)

Scheme 1.<smiles>[R]NC([R])C([R])=O</smiles>

(2)<smiles>[R3]CC([R])=O</smiles>

(3)<smiles>[R]c1c([R3])c([R])n([R])c1[R]</smiles>

(4)

$\mathrm{R}=\mathrm{H}$, aryl, alkyl;

$\mathrm{R}_{2}=$ alkyl, $\mathrm{CO}_{2} \mathrm{R} ; \mathrm{R}_{2}=$ alkyl, aryl;

$\mathrm{R}_{3}=$ electron-withdrawing group $(\mathrm{EWG})=\mathrm{COR}, \mathrm{CO}_{2} \mathrm{R}, \mathrm{CN} \mathrm{SO}_{2} \mathrm{R}$;

$\mathrm{R}_{4}=\mathrm{H}$, alkyl, aryl, $\mathrm{CO}_{2} \mathrm{R}$;

reducing agent: $\mathrm{Zn} / \mathrm{AcOH}, \mathrm{NaS}_{2} \mathrm{O}_{4}, \mathrm{Pd}(\mathrm{C}) / \mathrm{H}_{2}$, solvent; $\mathrm{AcOH}, \mathrm{H}_{2} \mathrm{O}$

Scheme 2 . 


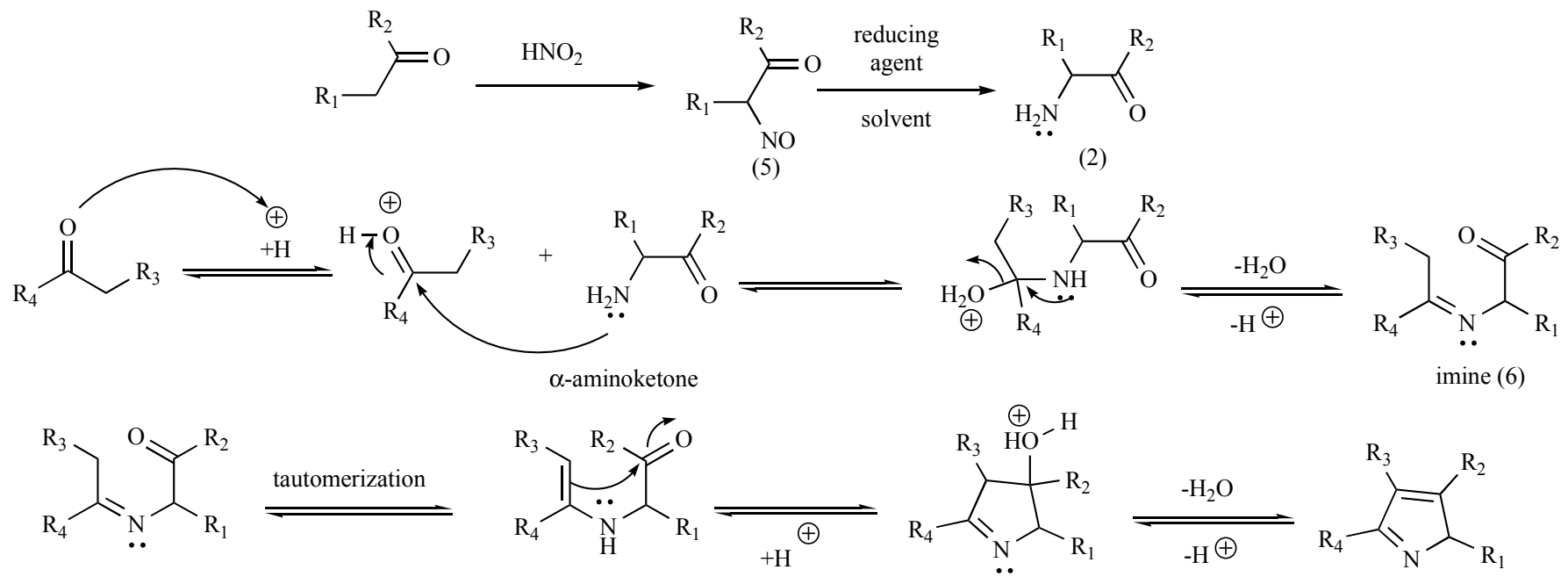

imine (6)

enamine (7)<smiles>[R]C1=NC([R])C([R])=C1[R]</smiles>

$\mathrm{R}^{1}=\mathrm{H}$, aryl, $\mathrm{CO}_{2} \mathrm{R}$

$\mathrm{R}^{2}=\mathrm{Alkl}$, aryl

$\mathrm{R}^{3}=$ electron-withdrawing group (EWG); $\mathrm{COR}, \mathrm{CO}_{2} \mathrm{R}, \mathrm{CN}, \mathrm{SO}_{2} \mathrm{R}$

(1)

$\mathrm{R}^{4}=\mathrm{H}$, alkyl, aryl, $\mathrm{CO}_{2} \mathrm{R}$

Reducing agent: $\mathrm{Zn} / \mathrm{CH}_{3} \mathrm{COOH}, \mathrm{Na}_{2} \mathrm{~S}_{2} \mathrm{O}_{4}, \mathrm{Pd}(\mathrm{C}) / \mathrm{H}_{2}$

Solvent: $\mathrm{CH}_{3} \mathrm{COOH}, \mathrm{H}_{2} \mathrm{O}$

Scheme 3.
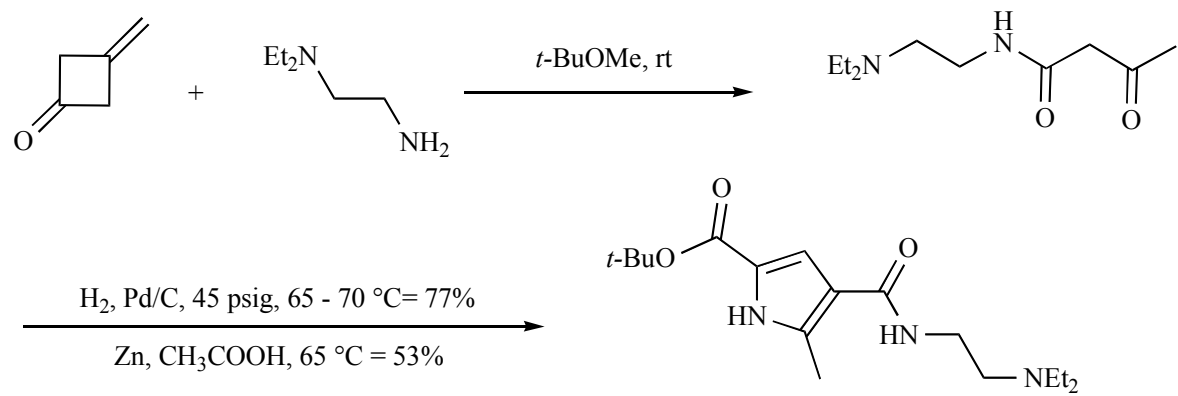

Scheme 4.

form the corresponding imine (6), and then a tautomeric equilibrium produces an enamine (7) that can be cyclized via nucleophilic attack on the carbonyl group in the intermediate. Finally, dehydration and tautomerization generate the pyrrole core (Scheme 3) [19].

Despite the efficiency in the reaction, the reduction process results in an environmental problem when it is carried out on a large scale; for this reason, the reduction with zinc dust is substituted by hydrogenation processes [19]. A clear example of this was given by Manley et al. [20] using $10 \%$ wt $\mathrm{Pd} / \mathrm{C}$, a reusable and cleaner catalyst to include the hydrogenation in the formation of the pyrrole ring instead of the reduction process with $\mathrm{Zn} / \mathrm{H}^{+}$to obtain $\alpha$ aminoketones. The palladium catalyst is more expensive, but it is recovered by filtration and can be reused because the $\mathrm{pH}$ changes due to the extraction of products generated from the acid medium do not affect its activity or composition producing contaminants, facilitating the separation of the products and a simple workup. In contrast, by alkalizing the reaction medium to precipitate the organic compound when the reducing agent is $\mathrm{Zn}$, the metal dissolves and different gelatinous co-precipitates are formed with the reaction products. These drawbacks are added to the environmental problems involved in the treatment of nonstoichiometric zinc salts. The disposal of the waste is an important condition to scale the process (first principle of Green Chemistry). By using $10 \mathrm{wt} \% \mathrm{Pd} / \mathrm{C}$, the yield increases to $24 \%$ (Scheme 4), achieving a more efficient methodology and a cleaner catalyst (see Table 1) (ninth principle of Green Chemistry).

Another way to make this process more environmentally friendly is by avoiding reductions, which is achieved with the use of fewer carbonyl reactive compounds than $\alpha$-aminoketones. Under this concept, Alberola et al. introduced the use of Weinreb $\alpha$ aminoamides (8) [21] to obtain $N$-methoxy- $N$-methyl- $\alpha$ enaminocarboxamides (9). The reaction of these compounds with organometallic derivatives of lithium, magnesium, and aluminum generates intermediates and after cyclizing, it produces polysubstituted pyrrole derivatives (10). The efficiency in the preparation of these intermediates depends on the substituents $-\mathrm{R}_{2}$ and $-\mathrm{R}$ (Scheme 5). When $-R_{2}$ is other than hydrogen, reactions with organolithium or organomagnesium compounds occur efficiently, and no effect of 
Table 1. Comparison between the $\alpha$-nitrosoketone reduction process with $\mathrm{Zn} / \mathrm{CH} 3 \mathrm{COOH}$ and other alternative methods.

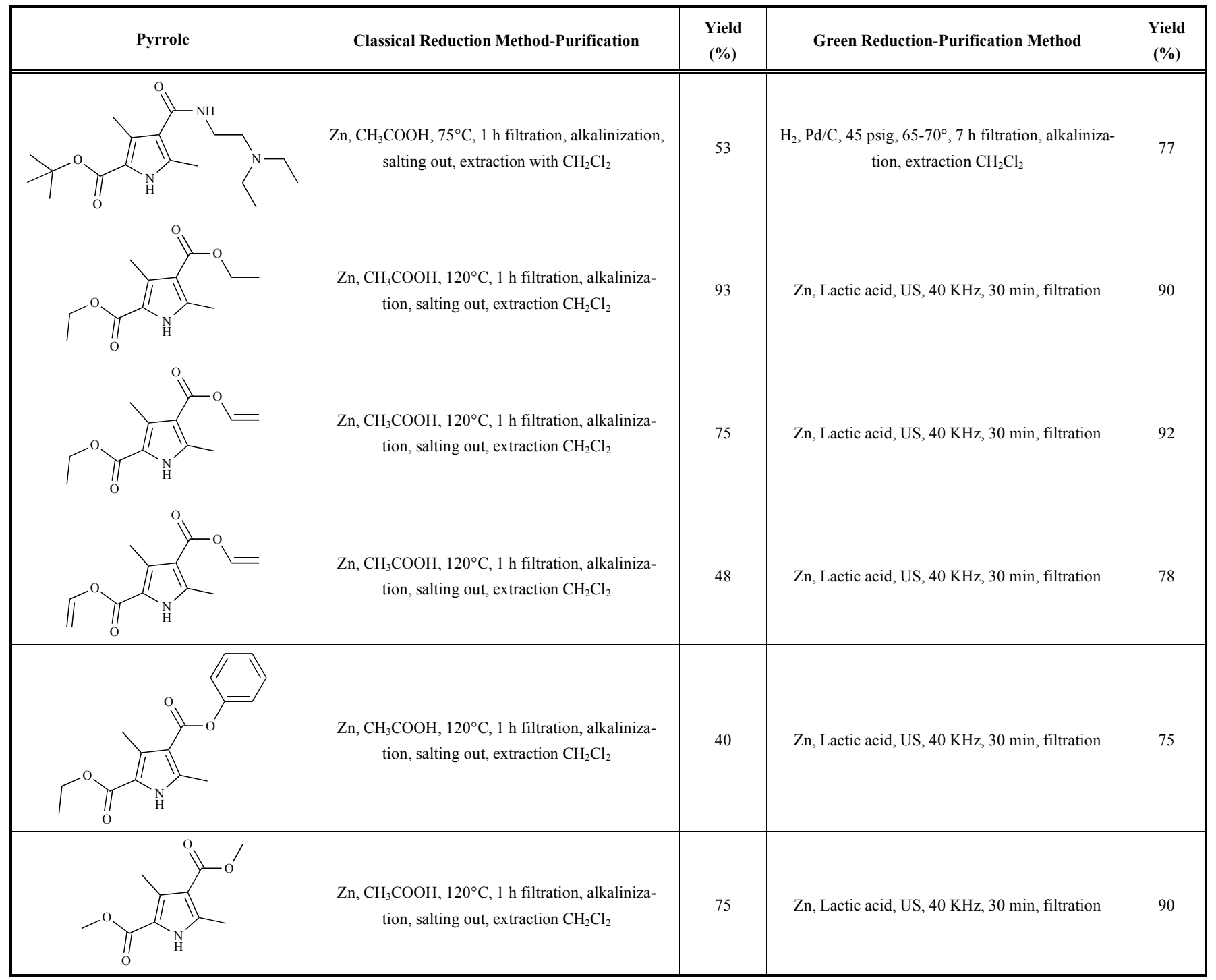

$-\mathrm{R}$ nature is observed. However, when $-\mathrm{R}_{2}=-\mathrm{H}$, the $-\mathrm{R}$ group is determinant; the yields are good when $\mathrm{R}=-\mathrm{CN}$ (enamine nitriles), but they decrease when $\mathrm{R}=-\mathrm{CO}_{2} \mathrm{Et}$ (enamine esters) and are very low for $\mathrm{R}=-\mathrm{COR}$ (enaminones). Following this methodology, pyrrole derivatives can range from $10 \%$ yields for enaminones up to $92 \%$ for enamine nitrile derivatives. Replacement of the intermediary influences the way in which the cyclization leads to the formation of pyrrole, which can be spontaneous using sodium ethoxide or silica as catalyst. All these difficulties make this process environmentally less attractive than the original one, as it requires contaminant solvents such as tetrahydrofuran, more complex reaction conditions (due to the use of organometallic compounds) and long reaction times.

Wang et al. [22] conducted the synthesis of 18 pyrrole derivatives by replacing the medium of acetic acid with lactic acid (see Table 1) (Scheme 6), a weaker acid that is less volatile than acetic acid with the advantage of being more easily recycled. Lactic acid shows good performance for the synthesis; as the products obtained are less soluble than acetic acid, pyrrole yields increase and the compound can be separated by simple filtration. The process also includes the use of ultrasound (frequency $40 \mathrm{kHz}$, power $500 \mathrm{~W}$ ), which increases the rate of reaction and avoids the use of high temperatures. Cavitation also facilitates the use of zinc because it pre- vents aggregation and passivation, which improves the reduction process of the metal dust. For this reason, the authors consider this synthesis route as a practical protocol for the industrial production of pyrrole derivatives.

\subsection{Paal-Knorr Method}

This synthetic method consists of a condensation process between the 1,4-dicarbonyl (11) compound and primary amines generally catalyzed by a Bronsted acid, Bronsted base or Lewis acids. The last condition can be used to obtain molecules with easily epimerizable functions in acid media; in this process, the carbonyl compound provides four carbon atoms in the pyrrole structure, while the amine provides the nitrogen atom [19]. However, the reaction is limited to amines without alkyl substituents in $\alpha$ position, which is the case of cyclohexylamine [23]. The reaction mechanism involves double amine condensation with the carbonyl compound and follows equivalent paths regardless of whether the reaction is catalyzed by a Bronsted acid or a Lewis acid (Scheme 7).

As shown, the Paal-Knorr reaction is a simpler reaction, but it is more versatile than other pyrrole synthesis methods since the starting reagents are stable and easy to achieve. For this reason, many modifications and improvements have been carried out, ranging from 


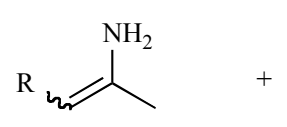

enamine

$\mathrm{R}=\mathrm{CN},-\mathrm{CO}_{2} \mathrm{Et}$,

$-\mathrm{COR}$<smiles>[R]C(N)C(=O)N(C)OC</smiles>

(8)

Weinreb $\alpha$-amide ( $N$-methoxy- $N$-methyl- $\alpha$ aminocarboxamides)

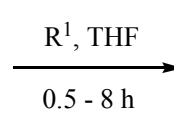<smiles>[R]C=C(C)NC([R2])C([R])=O</smiles>

$\mathrm{R}^{1}=\mathrm{H}, \mathrm{CH}_{3}, i$-pr

$\mathrm{R}^{2}=\mathrm{H}, \mathrm{CH} 3$, Ph, ethyl-1,3-dioxolano,

1,3-dithianyl, 2-methyl-1,3-dithiane

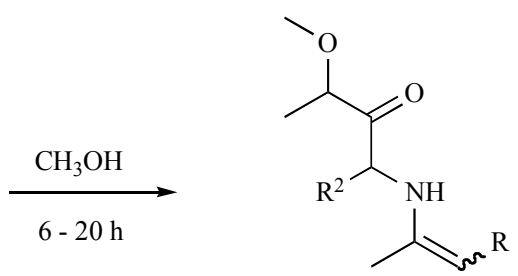

(9)

Weinreb $\alpha$-vynilamide$(N$-methoxy- $N$-methyl- $\alpha$ enaminocarboxamides)<smiles>[R]c1[nH]c(C)c([R])c1[R]</smiles>

(10)

28 examples 10 - $92 \%$ yields

Scheme 5.<smiles>[R]C(=O)CC([R])=O</smiles>

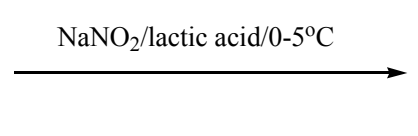<smiles>[R]C(=O)C(C([R])=O)[N+](=O)[O-]</smiles>

1,3-dicarbonyl compound/Zn/lacticacid

MW $40 \mathrm{KHz}$<smiles>[R2]C(=O)CCCCCC(=O)OCC</smiles><smiles>[R][R]=[R]([R])[R]</smiles>

18 examples $75-95 \%$ yields

Scheme 6.<smiles>[R]C(=O)C([R])C([R])C([R])=O</smiles>

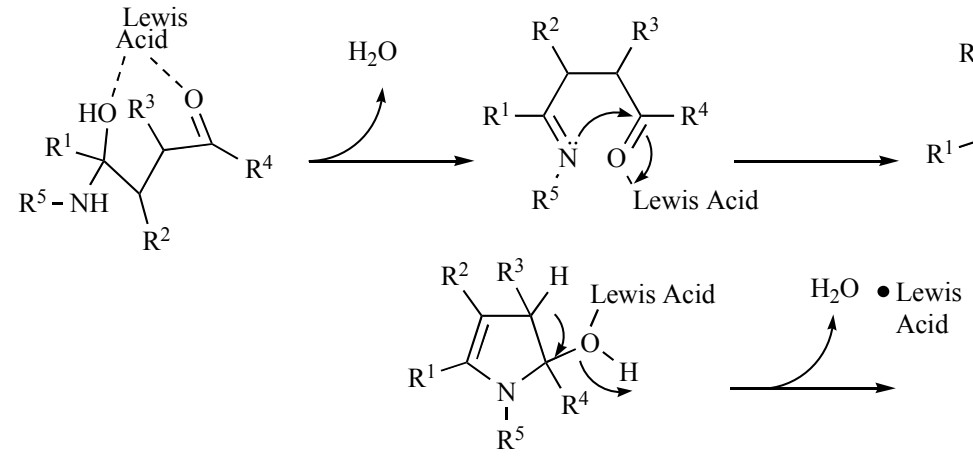

$\mathrm{R}^{1}=\mathrm{H}$, alkyl, aryll

$\mathrm{R}^{2-3}=\mathrm{H}$, alkyl, aryl, $\mathrm{CO}_{2}$-alkyl, $\mathrm{CO}_{2}$-aryl

$\mathrm{R}^{4}=\mathrm{H}$, alkyl, aryl

$\mathrm{R}^{5}=\mathrm{H}, 1^{\circ}, 2^{\circ}$ or $3^{\circ}$ alkyl, aryl, heteroaryl, $\mathrm{NR}_{2}, \mathrm{NH}_{2}, \mathrm{OH}, \mathrm{NH}_{4} \mathrm{OAC},\left(\mathrm{NH}_{4}\right)_{2} \mathrm{CO}_{3}$

Scheme 7. 
<smiles>[R]C(=O)CC(=O)OC</smiles>

a) $\mathrm{Et}_{2} \mathrm{Zn} / \mathrm{CH}_{2} \mathrm{I}_{2} / \mathrm{R}_{2} \mathrm{COSEt}$ or $\mathrm{R}_{2} \mathrm{CHO}$ or followed by $\mathrm{Et}_{2} \mathrm{Zn} / \mathrm{R}_{2} \mathrm{CHO}$

b) $\mathrm{PCC}, \mathrm{CH}_{2} \mathrm{Cl}_{2}, \mathrm{SiO}_{2}$ $\mathrm{CH}_{3} \mathrm{COOH}$ min, open vessel

$\mathrm{R}^{1}=t$-But, Et

$\mathrm{R}^{2}=$ Aryl alkyl

$\mathrm{R}^{3}=$ Aryl, alkyl<smiles>[R]C(=O)CC(C([R])=O)C([R])=O</smiles>

(13)<smiles>[R]NNC(=O)C([R2])C(=O)[18O]</smiles>

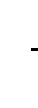<smiles>[R]c1cc(C(C)=O)c([R])n1[R3]</smiles>

35 examples $65-88 \%$ yield

Scheme 8.

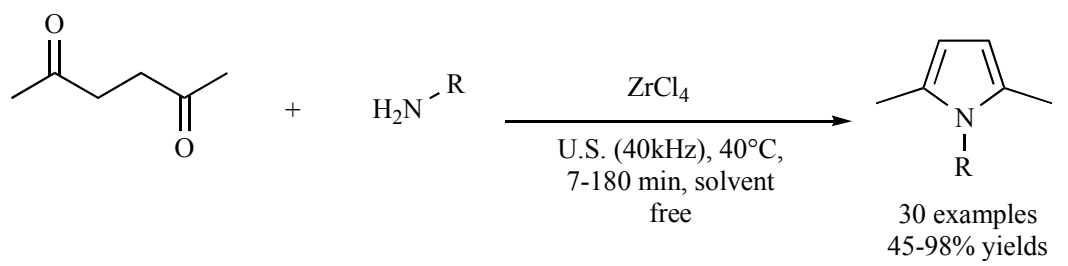

$\mathrm{R}=\mathrm{CH}_{2}=\mathrm{CHCH}_{2}, \mathrm{PhCH}_{2}, \mathrm{PhCH}\left(\mathrm{CH}_{3}\right), \mathrm{X}-\mathrm{Ph}$, naphthyl, 4-bromonaphthalen-1-yl, methyl-2-pyridinyl,5-methyl-2-pyridinyl

$\mathrm{X}=o-\mathrm{CH}_{3}, m-\mathrm{CH}_{3}, p-\mathrm{CH}_{3}, 2,3-\mathrm{CH}_{3}, 2,4-\mathrm{CH}_{3}, p-t-\mathrm{Bu}, 2,6-i-\mathrm{pr}, o-\mathrm{CH}_{3} \mathrm{O}, p-\mathrm{CH}_{3}$, $o-\mathrm{CH}_{3} \mathrm{CH}_{2} \mathrm{O}, p-\mathrm{CH}_{3} \mathrm{CH}_{2} \mathrm{O}, o-\mathrm{PhO}, 2,4-\mathrm{Cl}, 2,3-\mathrm{Cl}, o-\mathrm{Br}, p-\mathrm{Br}, m-\mathrm{F}_{3} \mathrm{C}, \mathrm{p}-\mathrm{NO}_{2}$, $4-\mathrm{CH}_{3} \mathrm{CH}_{2} \mathrm{O}^{-2}-\mathrm{NO}_{2}$

Scheme 9.<smiles>[R]N</smiles>

$\mathrm{R}=$ Aryl, Alkyl, naphthyl.<smiles>[R]C(=O)CCC([R])=O</smiles><smiles></smiles>
$\underset{\text { Ball mill (zirconia ball, }}{\longrightarrow}$ $30 \mathrm{~Hz}), \mathrm{rt}$

$$
\begin{gathered}
\mathrm{R}^{1}=\mathrm{R}^{2}=\mathrm{Me} \\
\text { or } \\
\mathrm{R}^{1=}=\mathrm{Me} ; \mathrm{R}^{2}=\mathrm{Ph}
\end{gathered}
$$

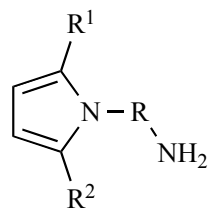

4 examples $12-80 \%$ yields<smiles>[R]c1ccc([R])n1[R]</smiles>

18 examples $8-80 \%$ yields

Monopyrrole<smiles>[R]c1ccc([R])n1[R]n1c([R])ccc1[R]</smiles>

4 examples $6-78 \%$ yields

Bis(pyrrole) (15)

Scheme 10.

the use of different types of Lewis acid catalysts and biodegradable catalysts [24], through unusual solvents such as ionic liquids [25], to the use of activation techniques such as microwave (MW) [26] and ultrasound (US) [27].

Among the new activation techniques, the most widely used is MW. This technique was used by Minetto et al. [28] for the synthesis of different 1,4-diketones that were transformed into pyrroles, furans and thiophenes by Paal-Knorr condensation. The reaction of a $\beta$-ketoester (12) with $\mathrm{Et}_{2} \mathrm{Zn} / \mathrm{CH}_{2} \mathrm{I}_{2}$ gives 1,4-diketones (13) with different functionalities such as alkyl and aromatic functions in $\mathrm{C} 1$ and $\mathrm{C} 4$ positions, and ester functionality in $\mathrm{C} 3$ position. The prepared diketones are used in the Paal - Knorr reaction assisted by microwave in acetic acid media, a biodegradable solvent that also functions as a catalyst (principles 1, 3, 5, 7 and 10 of Green Chemistry), to obtain the corresponding pyrrole derivatives. The best results are obtained in an open container at $120-150{ }^{\circ} \mathrm{C}$ for a time period from 2 to $10 \mathrm{~min}$; depending on the nature of the substrates used (conventional synthesis can take more than $24 \mathrm{~h}$ ), pyrrole yields may range from $65 \%$ to $88 \%$ (Scheme 8 ).
Zhang et al. [27] reported the synthesis of 2,5-dimetylsubstituted pyrroles (14) by ultrasound radiation from acetonylacetone, and alkyl or aromatic amines mediated by an inexpensive Lewis acid $\left(\mathrm{ZrCl}_{4}\right)$ to obtain high product yields in reaction times between 7 and $180 \mathrm{~min}$. The procedure takes place in a solvent-free medium, most products obtained are pure, and subsequent purification is not necessary (Scheme 9).

By using a "green acid" of biological origin as catalyst, such as citric acid, succinic acid, pyroglutamic acid, ascorbic acid, camphorsulfonic acid and oxalic acid, mechanical activation in ball mill yields a variety of N-pyrroles [29]. The most important topic of this work is the low amount of catalyst used for the process (1\%), citric acid being the most effective due its higher acidity. Pyrroles are obtained from acetonylacetone and 1-phenylpentane-1,4-dione, with moderate yields due to the great steric hindrance in the substrate, which causes a lower reactivity. The mild reaction conditions allow the synthesis of functionalized pyrroles with amine and alcohol groups, furthermore facilitating the synthesis of (bis)pyrroles (15) (Scheme 10). 
Table 2. Common catalysts used in the Paal-Knorr reaction.

\begin{tabular}{|c|c|c|c|c|}
\hline & Catalyst & & & \\
\hline Catalyst & Reaction Conditions & $\mathbf{t}$ & $\begin{array}{c}\text { Yield } \\
(\%)\end{array}$ & Ref. \\
\hline$\alpha-\mathrm{Zr}\left(\mathrm{KPO}_{4}\right)_{2}$ & $60^{\circ} \mathrm{C}$, solvent-free & $24 \mathrm{~h}$ & 56 & {$[30]$} \\
\hline$\alpha-\mathrm{Zr}\left(\mathrm{CH}_{3} \mathrm{PO}_{3}\right)_{1.2}\left(\mathrm{O}_{3} \mathrm{PC}_{6} \mathrm{H}_{4} \mathrm{SO}_{3} \mathrm{H}\right)_{0.8}$ & $60^{\circ} \mathrm{C}$, solvent-free & $2 \mathrm{~h}$ & 88 & [30] \\
\hline $\mathrm{Sc}(\mathrm{OTf})_{3}$ & $35^{\circ} \mathrm{C}$, solvent-free & $25 \mathrm{~min}$ & 93 & [32] \\
\hline $\mathrm{H}_{3} \mathrm{NSO}_{3}$ & rt, solvent-free & $30 \mathrm{~min}$ & 92 & [33] \\
\hline Molybdosulfuric acid & $60^{\circ} \mathrm{C}$, solvent-free & $40 \mathrm{~min}$ & 96 & [35] \\
\hline $\mathrm{Fe}^{3+}$-montmorillonite & Rt, $\mathrm{CH}_{2} \mathrm{Cl}_{2}$ & $3 \mathrm{~h}$ & 96 & [36] \\
\hline PEG-SO ${ }_{3} \mathrm{H}$ & Rt, water & $8 \mathrm{~h}$ & 92 & [41] \\
\hline $\mathrm{Bi}\left(\mathrm{NO}_{3}\right)_{3} \cdot 5 \mathrm{H}_{2} \mathrm{O}$ & Rt, solvent-free or $\mathrm{CH}_{2} \mathrm{Cl}_{2}$ & $10 \mathrm{~h}$ & 96 & [42] \\
\hline$\beta$-cyclodextrin & $60^{\circ} \mathrm{C}$, water & $24 \mathrm{~h}$ & 86 & [44] \\
\hline
\end{tabular}

Several kinds of catalysts are used in the Paal-Knorr condensation (see Table 2), all them are different, including Lewis acids and Bronsted acids as diverse as $\alpha-\mathrm{Zr}\left(\mathrm{CH}_{3} \mathrm{PO}_{3}\right)_{1.2}\left(\mathrm{O}_{3} \mathrm{PC}_{6} \mathrm{H}_{4} \mathrm{SO}_{3} \mathrm{H}\right)_{0.8}$ and $\alpha-\mathrm{Zr} \quad\left(\mathrm{KPO}_{4}\right)_{2}$ [30], $\mathrm{Bi}\left(\mathrm{NO}_{3}\right)_{3} \cdot 5 \mathrm{H}_{2} \mathrm{O} \quad$ [31], $\mathrm{Sc}(\mathrm{OTf})_{3}$ [32], $\mathrm{H}_{3} \mathrm{NSO}_{3}$ [33], $\mathrm{CF}_{3} \mathrm{COOH}$ [34] or molybdosulfuric acid [35], to name only a few. However, many catalysts are expensive and composed of transition metals and difficult to synthesize anions. In many cases, the catalyst synthesis involves significant energy waste or complex processes for its production and purification. The fact that many of the heavy metal cations in the catalyst structure are in toxic oxidation states and the anions are nonbiodegradable or accumulative only adds to the problem, because these compounds cannot be reused easily and many of them are corrosive.

Clays are safer and friendlier catalysts for this transformation. These catalysts derive from modified montmorillonites [36] with metals of the first transition series through cation exchange. The $\mathrm{Fe}^{3+}$-montmorillonite (see Table 2 ) is an inexpensive, noncorrosive and recyclable catalyst. The Paal-Knorr reaction using this catalyst is carried out under mild reaction conditions (room temperature) to obtain high yields (69\%-96\% for alkyl and aryl amines with 2,5hexanedione) in short reaction times ( 1 to $6 \mathrm{~h}$ ) and involves a simple purification step of the products, and the catalyst can be reused three times without loss of its catalytic activity. Insoluble heterogeneous catalysts can be recovered by simple filtration or centrifugation, in all kinds of solvents, as in the case of clays, acid resin Amberlite IR 120 [37], and tungstosulfuric acid [38], or by using a magneto, as in the case of the magnetically modified sulfuric acid $\left(\gamma-\mathrm{Fe}_{2} \mathrm{O}_{3}-\mathrm{SiO}_{2} @ \mathrm{OSO}_{3} \mathrm{H}\right)$ [39], an inexpensive reusable catalyst of simple synthesis that can be used in solvent-free media with high efficiency in 2,5-dimethylsubstituted pyrrole and (bis)pyrrole derivative synthesis.

An important trend is the use of green catalysts that not only can be reused but are also biodegradable, some being obtained from biomass such as xanthan [40] or from synthetic polymeric structures such as PEG [41].
Jafari et al. [41] synthesized various pyrroles (16 examples) and (bis)pyrroles ( 3 examples) using $\mathrm{PEG}-\mathrm{SO}_{3} \mathrm{H}$ as catalyst. The process is attractive because pyrroles are isolated in high yields $(87 \%$ $98 \%$ ), it achieves a high degree of purity (first principle of Green Chemistry) and it is carried out in an aqueous medium. Recovery involves only a filtration step (fifth and eighth principles of Green Chemistry), although reaction times range from 2 to $24 \mathrm{~h}$. The catalyst shows high substrate selectivity (Scheme 11). The conversion of aliphatic amines is highly selective in comparison with that of aromatic amines. A similar behavior occurs with substituted anilines with carbonyl electron-withdrawing groups in comparison with unsubstituted aniline. This shows the importance of the electronic effects and nucleophilicity of the electron pair on nitrogen in the Paal-Knorr reaction catalyzed by $\mathrm{PEG}-\mathrm{SO}_{3} \mathrm{H}$. In this case, the catalyst is easily recovered and can be reused up to four times without loss of activity.

This approach contrasts with the use of other catalysts in polymer base, as reported by Banik et al. [42] (polystyrene sulfonate). It can be considered more environmentally friendly because of shorter reaction times for aromatic amines (comparison based on the product of unsubstituted aniline) under similar reaction conditions with the advantage that PEG- $\mathrm{SO}_{3} \mathrm{H}$ is a biodegradable substance.

Natural biopolymers such as xanthan are attractive solid supports because they are eco-friendly products from renewable sources. Catalysts such as sulfuric acid supported on xanthan show high yields in the Paal-Knorr synthesis and achieve a lower time reduction compared to inorganic catalysts such as bismuth nitrate or indium triflate, as in advanced activation techniques such as MW [28]. Other harmless materials are also used directly as catalysts in the Paal-Knorr reaction under mild conditions using environmentally friendly solvents such as alcohols or water, as in the case of artificial sweeteners such as saccharin [43] and some sugar derivatives such as $\beta$-cyclodextrin [44], obtaining good results.

An alternative to the usual procedures consists of carrying out the Paal-Knorr reaction with alternative solvents such as ionic liq- 

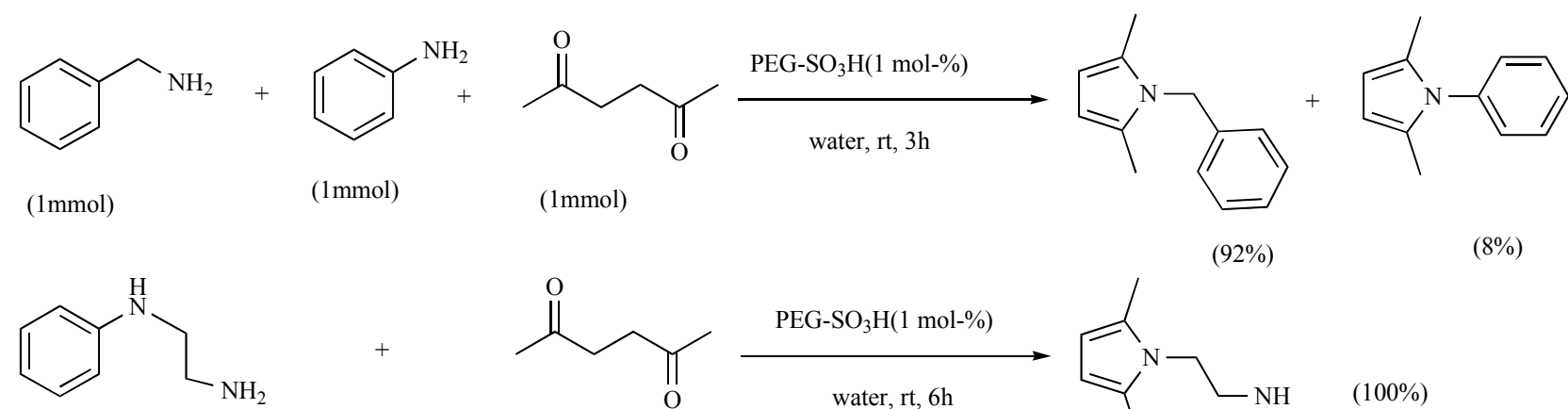<smiles>CCCCCCCCCC</smiles>
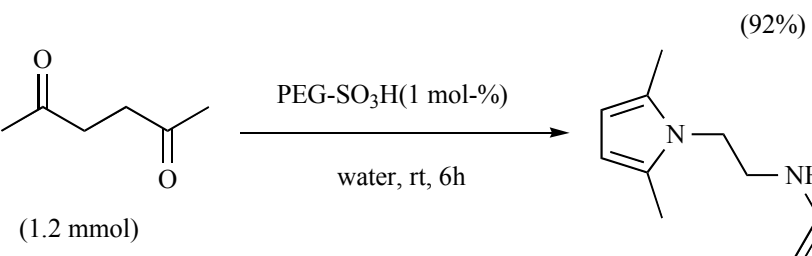

$(8 \%)$

(1 mmol)<smiles>Nc1ccccc1</smiles>

(1mmol)<smiles>CC(=O)c1cccc(N)c1</smiles>

(1mmol)

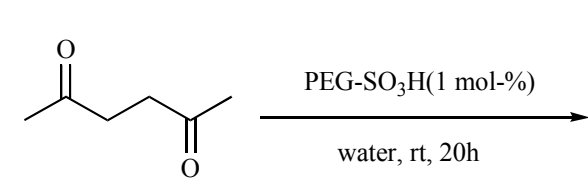

(1mmol)

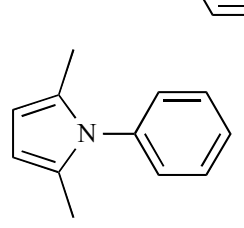

(96\%)<smiles>Nc1ccccc1</smiles>

Scheme 11.

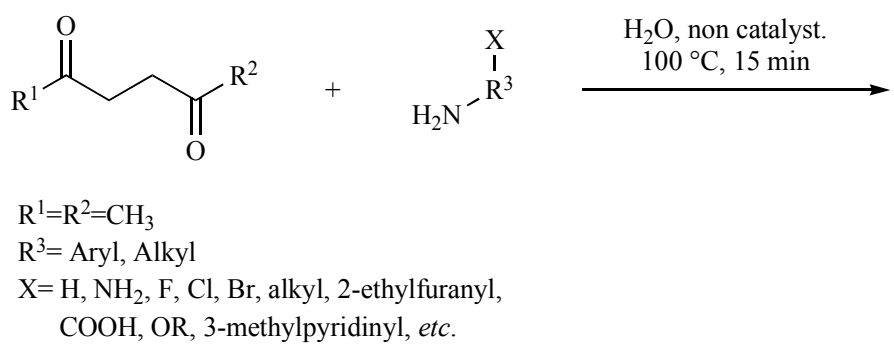<smiles>[R]c1ccc([R])n1[R]</smiles>

18 examples $75-98 \%$ yields

Scheme 12.

$$
\begin{aligned}
& \mathrm{R}^{1}=\mathrm{R}^{2}=\mathrm{CH}_{3}, \\
& \mathrm{R}^{3}=\mathrm{Alkyl}, \mathrm{Aryl} \\
& \mathrm{X}=\mathrm{H}, \mathrm{NH}_{2}, \mathrm{~F}, \mathrm{Cl}, \mathrm{Br} \text {, akyl, aryl, } \mathrm{F}_{3} \mathrm{C}, \mathrm{SH}
\end{aligned}
$$

Catalyst and solvent free, RT or $100^{\circ} \mathrm{C}, 15 \mathrm{~min}-80 \mathrm{~h}$<smiles>[R]c1ccc([R])n1[R]</smiles>

44 examples $32-100 \%$ yields

Scheme 13.

uids [45], water [46], and under solvent and catalyst-free conditions (Scheme 12). In the subsequent cases, although the process may take a while longer for the reaction of some substrates, the procedure becomes simpler, more selective and environmentally friendlier due to the high atom economy, low energy consumption (it prevents conventional heating), and being a condensation reaction, the only by-product of the process is water, covering most of the principles of Green Chemistry [47]. Under this guideline, Cho et al. synthesized 47 different pyrroles from various diketones and amines, obtaining quantitative yields for some of the pyrrole derivatives in times ranging from $15 \mathrm{~min}$ to $80 \mathrm{~h}$ of reaction (Scheme 13).

\subsection{Hantzsch Pyrrole Reaction}

The Hantzsch method is a clear example of a multicomponent reaction [16] in which multiple reactions are combined in a single synthetic operation that leads to the formation of a compound, in this case pyrrole. It maximizes the inclusion of atoms in the reactants in the final product, so it fully meets the second principle of
Green Chemistry known as the atom economy principle. While the reaction itself can be considered an environmentally compatible process because of the efficient yields and the aforementioned atom economy [48], there are many studies in which the reaction has been experimentally modified to make it even more environmentally friendly. The first step consists of developing a solvent-free reaction or replacing the commonly used solvents in the process such as DMF, toluene, chloroform, acetonitrile, THF, etc. with less polluting solvents such as methanol, ethanol or water.

It corresponds to the formation of substituted pyrroles from $\beta$ ketoesters with $\alpha$-haloketones (16) in ammonia or primary amine media (Scheme 14). The reaction mechanism proceeds via enamine: under heating the fast attack of amine on the $\beta$-ketoester occurs; at this point, the enamine ester (3-aminocrotonate) formed is cyclized with the $\alpha$-haloketone to form the pyrrole. As one of the intermediaries corresponds to 3-aminocrotonate, the reaction can be initiated with this kind of compound. The regioselectivity of the derivative is completely dependent on the substituents in the starting reagents, 


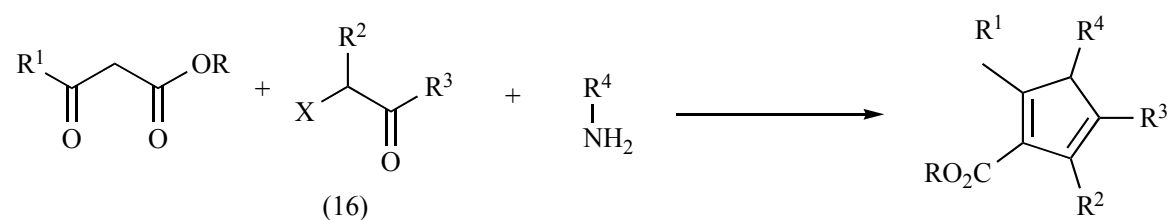

$\mathrm{R}^{1}, \mathrm{R}^{2}, \mathrm{R}^{3}, \mathrm{R}^{4}=\mathrm{H}$, alkyl, aryl,

$\mathrm{R}=$ alkyl, aryl

$\mathrm{X}=\mathrm{Cl}, \mathrm{Br}$, I, etc.

Scheme 14.
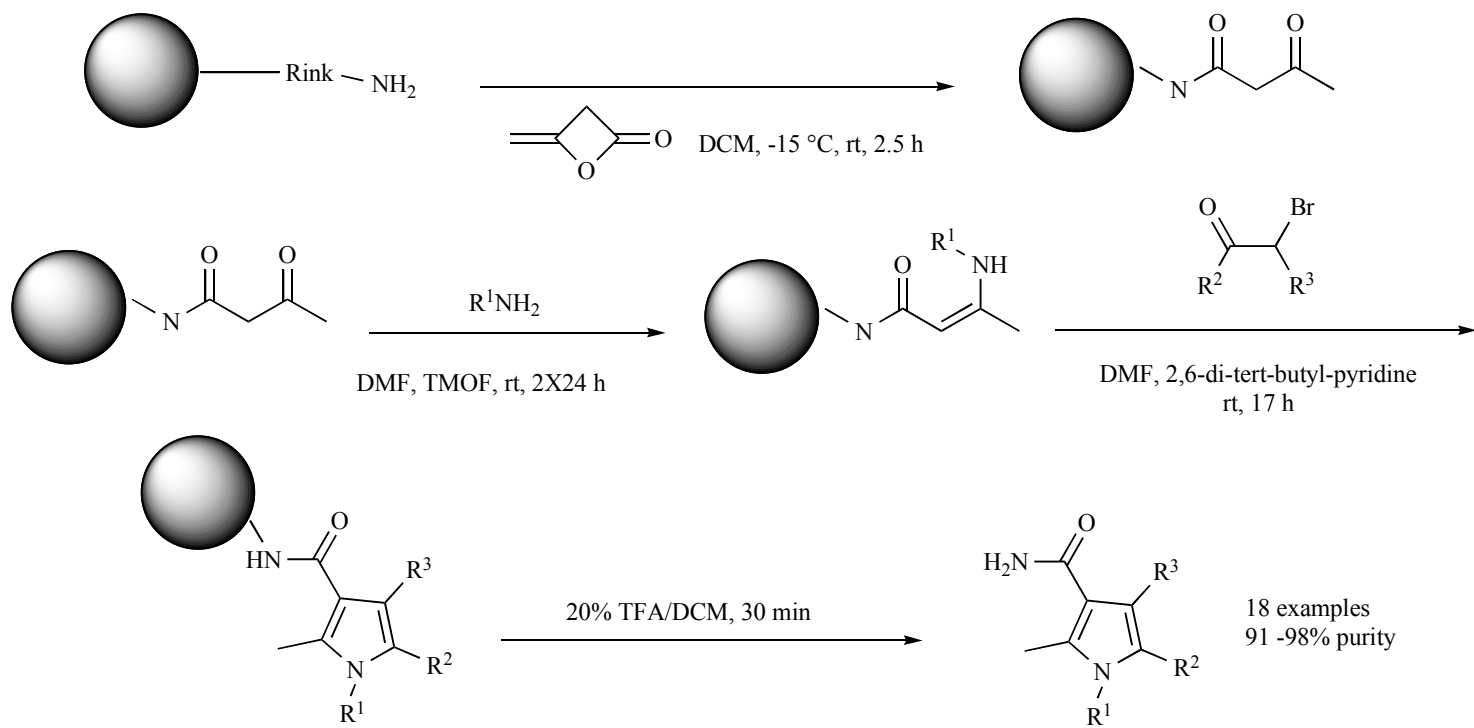

18 examples $91-98 \%$ purity

$\mathrm{R}^{1}=\mathrm{PhCH}_{2} \mathrm{CH}_{2}, \mathrm{HOCH}_{2} \mathrm{CH}_{2}$, cyclopropyl, piperonyl, $n$-Bu, 2-furfuryl,yl, allyl, propargyl, tyraminyl, histaminyl, 2-(thiophen-2-yl)ethyl, 4-ethylmorpholine $\mathrm{R}^{2}=\mathrm{X}-\mathrm{Ph},\left[1,1\right.$ '-biphenyl]-4-yl, 2,5-dimethoxyphenyl, $\mathrm{CH}_{3} \mathrm{CH}_{2}, 3-(2,4-$ dichlorophenyl)isoxazol-5-ylm $\mathrm{CO}_{2} \mathrm{H}_{2} \mathrm{CH}_{3}$, naphtyl $\mathrm{X}=\mathrm{H}, p-\mathrm{Cl}, p-\mathrm{CN}, p-\mathrm{F}, 3,4-\mathrm{Cl}, m-\mathrm{CH}_{3} \mathrm{O}, m-\mathrm{NO}_{2}$ $\mathrm{R}^{3}=\mathrm{H}$

Scheme 15.

and when the process is performed from aromatic amines, indoles or carbazoles are available if cyclization occurs with $\alpha$ halocyclohexanones [49].

From a chemical point of view, the Hantzsch pyrrole synthesis is a more versatile process in comparison with Paal-Knorr and Knorr syntheses, because it no longer depends on achieving inaccessible intermediates such as symmetrical $\alpha$-aminoketones or compounds such as 1,3-diketones, and it does not form compounds with specific substitution such as 2,5-dialkypyrroles or $\mathrm{N}$ substituted pyrroles [50].

Trautwein et al. developed a method for the solid phase synthesis of a pyrrole series using a Rink amide resin support [51]. The first step in the process is the conversion of the solid support to enamine, in order to continue the condensation of the enamine with the corresponding $\alpha$-bromoketone to finally get the pyrrole ring (Scheme 15). During the process, the reaction time with the selected $\alpha$-bromoketone is $3 \mathrm{~h}$, yielding pyrrole species with purities up to $98 \%$. Under similar conditions, compounds with purities between $80 \%$ and $90 \%$ can be obtained when the $\alpha$-bromoketone is replaced with an aldehyde and a nitroalkane combination or a nitroalkene [52]. However, one of the great difficulties of this methodology is the highly polluting solvents used and the long reaction times needed in the Rink amide support functionalization and their respective enamine conversion. Despite these disadvantages, one of the main attractions of this synthesis is the possibility of automation and the functionalization of the support for obtaining pyrrole at room temperature. This development is useful in combinatorial synthesis in drug discovery due to the great biological activity that pyrrole derivatives have.

Automation of the Hantzsch reaction was performed by Herath et al. [53] with an approach to continuous flow chemistry [54]. The process takes place in a microreactor containing pyrrole-3carboxilic acids (17) and pyrrole-3-carboxilic highly substituted esters (18) with yields above $40 \%$. The technique involves a $1 \mathrm{~mL}$ glass reactor with two injection points at which the preheated solutions of the reactants in DMF are introduced, the reactor temperature is maintained at $200^{\circ} \mathrm{C}$, and the time in the reactor is no longer than 8 min (Scheme 16). Yields are excellent but high-cost special equipment is required; however, this process has the potential to perform multistep reactions in a single step. The benefits of this method are the short reaction time and efficient production of a large number of compounds with high purity. It also remains consistent with other principles of Green Chemistry, the first, which involves reducing by-products, and the eleventh, involving easy online process monitoring for pollution prevention.

Continuous processes are highly attractive and some of their advantages were already mentioned. However, in chemical produc- 


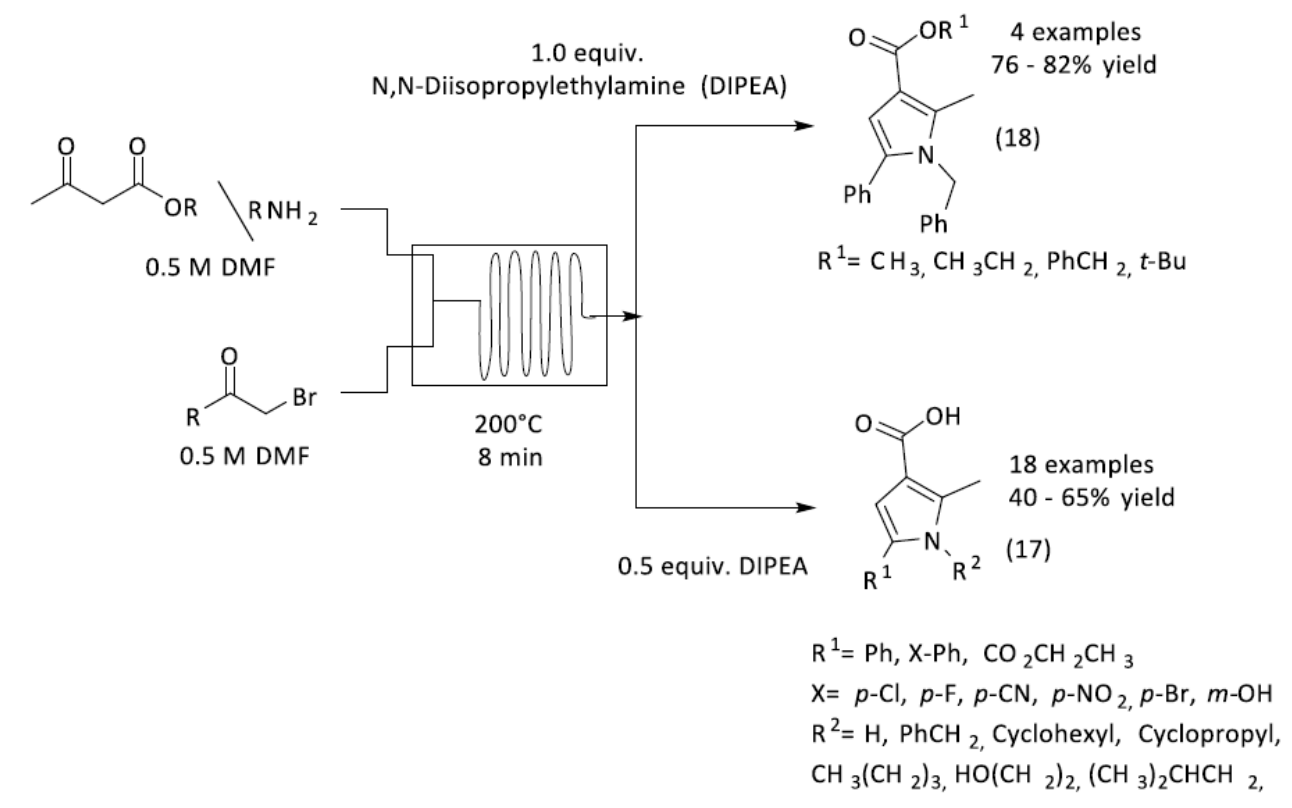

Scheme 16.

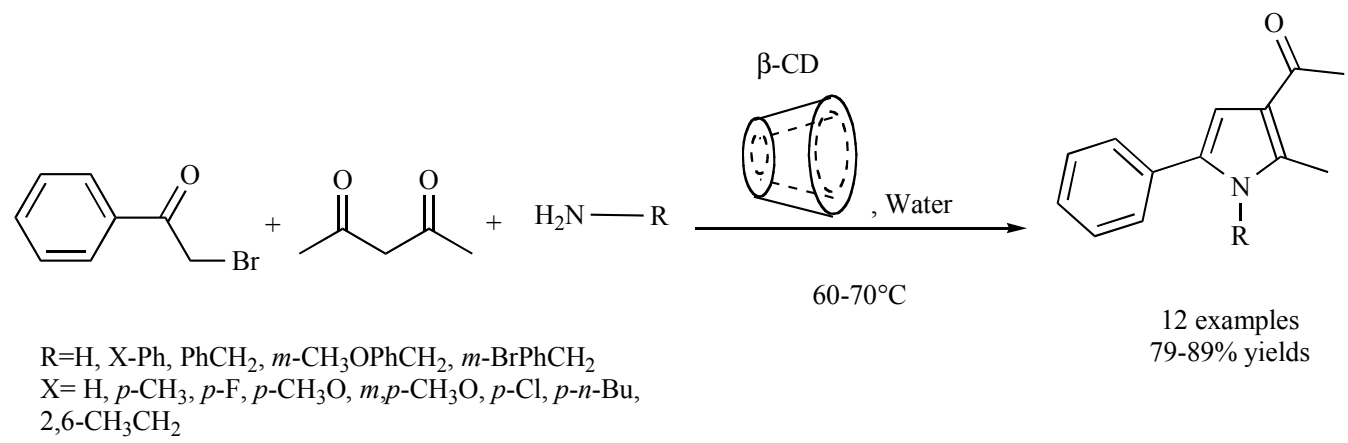

Scheme 17.<smiles>[R]C(=O)C([R])Cl</smiles><smiles>[R]c1[nH]c(C=O)c(C#N)c1[R]</smiles>

$\mathrm{R}, \mathrm{R}_{1}=\mathrm{H}, \mathrm{CH}_{3}{ }^{-},-\left(\mathrm{CH}_{2}\right)_{4}^{-}$

10 examples 38-66 yields

Scheme 18.

tion on a small scale, batch processes predominate due to technological, socioeconomic and human factors [55].

This multicomponent reaction has been developed in different ways, in many of which the process involves the use of catalysts that may be organic or inorganic and some of them, more environmentally friendly than others [56]. In connection with the use of an environmentally friendly catalyst, Murthy et al. [57] developed the process using $\beta$-cyclodextrin, a supramolecular catalyst; in this process various pyrrole derivatives are obtained in aqueous media. The yields of 1,5-diarylsubstituted pyrroles obtained are between $79 \%$ and $89 \%$ (Scheme 17), and the organic solvents are replaced with water (fifth principle of Green Chemistry). The green and biodegradable catalyst is highly effective (ninth principle of Green Chemistry) under mild temperature conditions $\left(60-70{ }^{\circ} \mathrm{C}\right)$ and can be reused more than once without considerable loss of activity. $\beta$ -
Cyclodextrin acts like a bowl forming an inclusion complex with the 2-bromoacetophenone that reacts directly with the 2,4pentanedione before the amine. This reaction does not proceed via $\beta$-enaminone, which explains why the reaction occurs with arylamine, an unusual substrate for the Hantzsch reaction.

The Hantzsch reaction has been generalized by Moss and Nowak [58] to obtain different labile functionalities in the structure of the pyrrole derivatives, as in the case of substitution by reactive groups such as aldehyde and cyano groups in 2 and 3 positions. This result was achieved by replacing the dicarbonyl compound with ketonitrile to form an enamine with ammonium acetate. The formed intermediates react with chloroacetaldehyde to give the heterocyclic compound (Scheme 18). The process affords yields of around $45 \%$ in one step at a temperature of $80^{\circ} \mathrm{C}$, in aqueous media and catalyst-free conditions. 


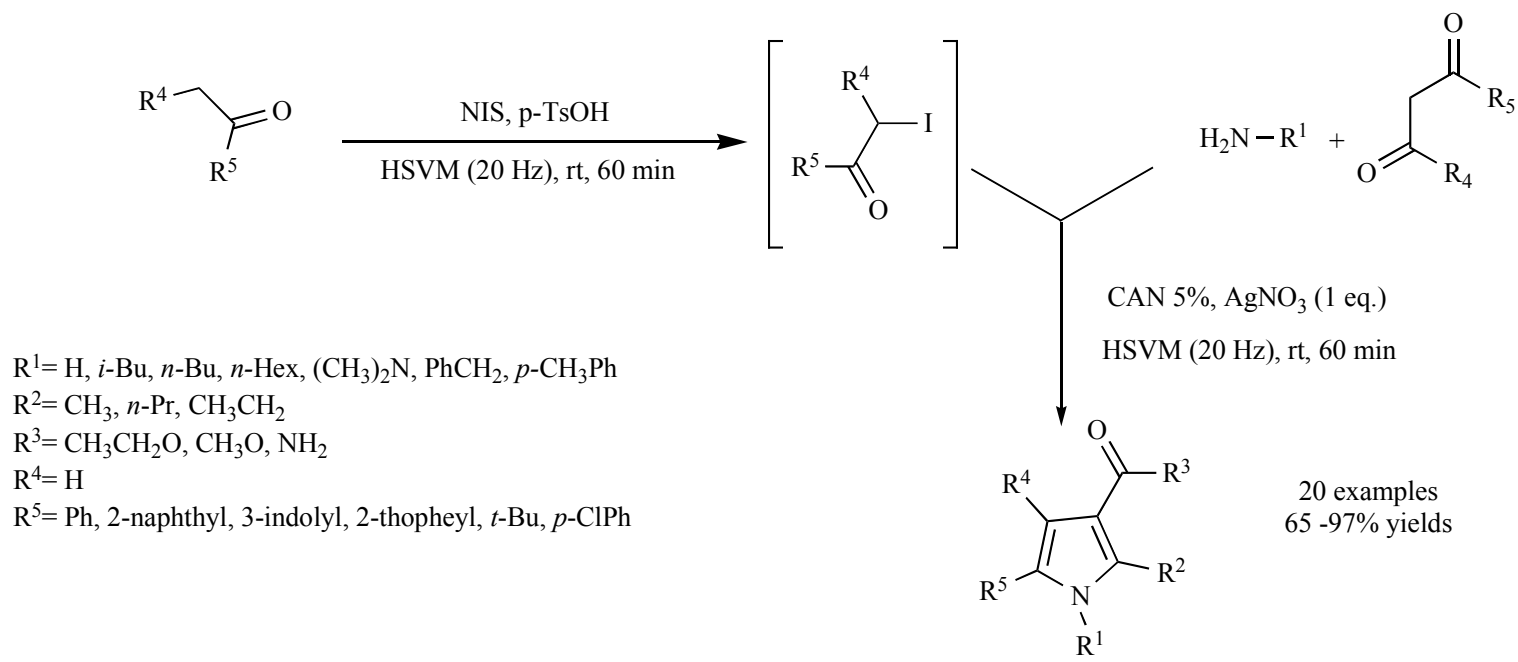

Scheme 19.

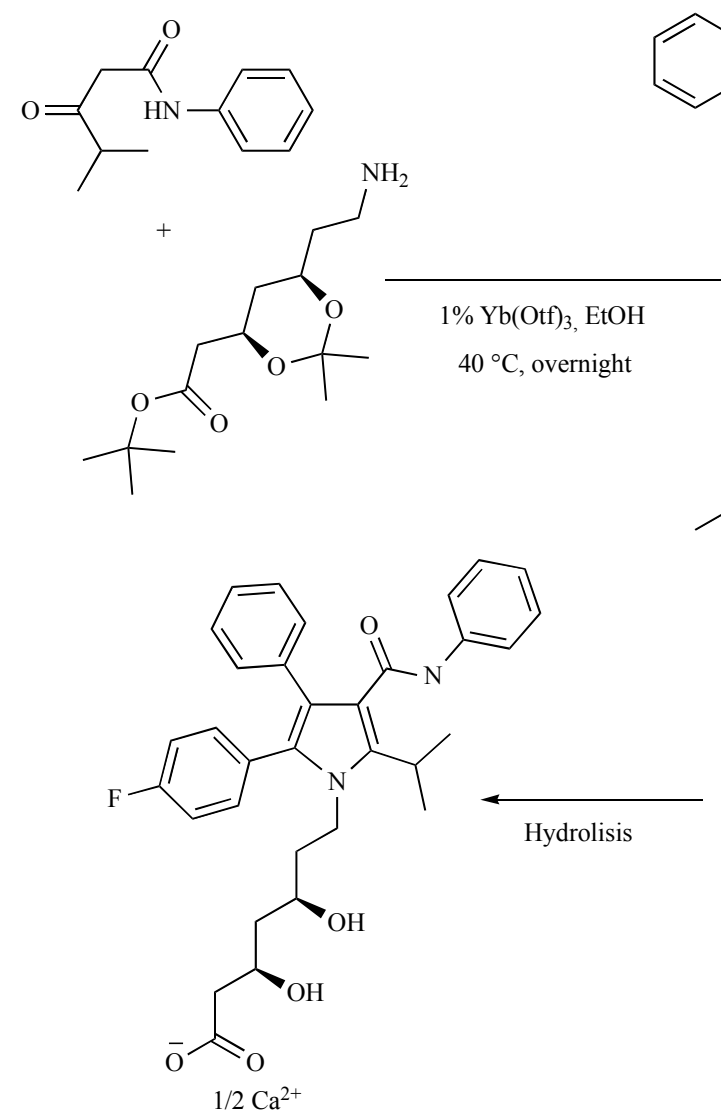

Scheme 20.

Despite the low yield in the process, the reaction is performed under catalyst-free conditions, achieving part of the concept of sustainable chemistry. In the same way, Eftekhari-Sis et al. [59] reported an efficient method for the preparation of 5-aryl-4hydroxy-2-methyl-1H-pyrrole-3-carboxylic acid esters from arylglyoxal hydrates with $\beta$-dicarbonyl compounds in the presence of ammonium acetate. The method involves the use of an ultrasound system at room temperature (sixth principle of Green Chemistry) in which the preparation times are reduced to 3-5 $\mathrm{min}$ from $30-60$ min in the conventional method. After completion of the reaction, the solid product is isolated by simple filtration without purification steps (first principle of Green Chemistry).
Mechanochemistry is another novel chemical activation technique that allows pyrrole derivative synthesis. Mechanochemistry is an energy efficient alternative that reduces or avoids the use of solvents by using a high frequency grinding process with tiny beads of an inert material to generate reactions (high-speed vibration milling, HSVM). The grinding is achieved by the strong impact of inert material balls that move with the reactants and catalysts in a container mill vibrating rapidly. Chemical reactions occur in places where the balls collide, where the impact generates localized heat and pressure points for short periods of time, thus the mechanical energy is then used to generate chemical changes. Estevez et al. [60] applied this technique, improving yields to obtain new pyrrole 
<smiles>[R]NCC([R])=O</smiles>

$$
\begin{aligned}
& \text { n: } 0-1 \\
& \mathrm{R}^{1}=\mathrm{m}-\mathrm{Bu}, \mathrm{CH}_{3}, \mathrm{n}-\mathrm{Hex}, \mathrm{PhCH}_{2} \\
& \mathrm{E}^{2}=\mathrm{n}-\mathrm{Pr}, \mathrm{CH}_{3} \\
& \mathrm{R}^{3}=\mathrm{CH}_{3} \mathrm{CH}_{2} \mathrm{O}, \mathrm{NH}_{2}, \mathrm{CH}_{3} \\
& \mathrm{R}^{4}=\mathrm{H}, \mathrm{CH}_{3} \\
& \mathrm{R}^{5}=\mathrm{H}, \mathrm{CH}_{3} \\
& \mathrm{R}^{6}=\mathrm{H}, \mathrm{CH}_{3} \mathrm{O} \\
& \mathrm{R}^{7}=\mathrm{H}, \mathrm{CH}_{3}
\end{aligned}
$$

\section{Scheme 21.}

derivatives with rare substitutions at position 5, such as phenyl, 2naphthyl, 3-indolyl and 2-thienyl, achieving excellent yields.

The reaction is simple at room temperature in a combination of a multicomponent and one-pot reaction, starting with the ketone and $\mathrm{N}$-iodosuccinimide (NIS) in the presence of p-toluenesulfonic acid (pTsOH) to obtain $\alpha$-iodoketone. After 60 min of milling at 20 $\mathrm{Hz}$, a mixture of the primary amine, a $\beta$-dicarbonyl compound, $5 \%$ ceric ammonium nitrate (CAN) and silver nitrate, in equivalent ratio to the starting ketone in the process, is added to the $\alpha$ iodoketone formed (Scheme 19). The mixture is ground for $1 \mathrm{~h}$ under the same conditions, obtaining yields between $65 \%$ and $90 \%$.

The same authors [61] reported the same process for the synthesis of a molecule of pharmacological interest, atorvastatin, a pharmacological agent that is lipid-lowering (hypolipemiant). This work is the first report on the formation of the heterocyclic core of this molecule. To carry out the process, CAN is replaced with another catalyst because of its activity on the hydrolysis of acetals, ytterbium triflate being the most suitable replacement. Using this methodology, atorvastatin was isolated with a yield of $38 \%$ (Scheme 20).

Menéndez group performed a comparative study for obtaining substituted pyrroles by classical reflux in an organic solvent and HSVM [62]. In this study, the reaction is optimized by comparing the behavior of different Lewis acids as catalysts, time and frequency of vibration milling, and the ratio $\beta$-enaminone $/ \alpha-$ iodoketone, obtaining a regioselective and efficient process. By using this methodology, a set of 35 polysubstituted pyrrole derivatives with substituents in all positions of the pyrrole structure, including the nitrogen atom, is achieved. Alkyl and aryl groups, with yields ranging between $32 \%$ and $97 \%$ in some alternative methodologies, have higher yields. Likewise, 16 examples of pyrrole fused systems (19), resulting from 4,5-dihydro-1H-benzo[g]indole, 1,4dihydroindeno[1,2-b]pyrrole, 4,5,6,7-tetrahydro-1H-indole and 1,4,5,6,7,8-hexahydrocyclohepta[b]pyrrole, can be obtained with efficiencies above $45 \%$ in all cases (Scheme 21). Although in some cases HSVM has lower yields, this technique has several advantages that make it environmentally friendly, including the solventfree medium (fifth principle of Green Chemistry), the combination of two methodologies for reducing waste, i.e., a multicomponent reaction and mechanochemical activation (principles 1, 2, 6 of Green Chemistry) and finally, the use of an efficient catalyst (ninth principle of Green Chemistry).

\subsection{Other Common Reactions}

\subsubsection{Other Multicomponent Reactions}

Multicomponent reactions (MCRs) are convergent reactions, in which three or more starting materials react to form a product, where basically all or most of the atoms contribute to the newly formed product. In an MCR, a product is assembled according to a cascade of elementary chemical reactions. Thus, there is a network of reaction equilibria, by which all reactions finally flow into an irreversible step yielding the product. The challenge is to conduct an MCR in a way that the network of pre-equilibrated reactions channels into the main product and does not yield side products. The result is clearly dependent on the reaction conditions: solvent, temperature, catalyst, concentration, the kind of starting material and functional group. Such considerations are of particular importance in connection with the design and discovery of novel MCRs [63].

A convenient one-pot multicomponent reaction of aromatic aldehydes, 1, 3-dicarbonyl compounds, amine and nitromethane in the presence of $10 \mathrm{~mol} \% \mathrm{ZnO}$ nanoparticles for the synthesis of highly substituted pyrroles (Scheme 22), was described by Matloubi Moghaddam et al. [64]. The products are obtained with moderate to good yields. This method offers several advantages, such as good yields, a simple procedure, nonhazardous reaction conditions, and easily accessible substrates as starting material.

Another multicomponent reaction was developed by Vivekanand [17]; the procedure follows a catalyst-free methodology in which a number of green solvents, such as ethanol, water, PEG200 , glycerol and lactic acid, are tested for the sequential reaction that involves enamine formation, Michael addition and cyclization of primary amines, 1,3-dicarbonyl compounds and isatin-derived compounds that afforded 3-(1H-pyrrol-3-yl)indolin-2-ones (20) (Scheme 23). Using water, glycerol, PEG-200 and a solvent-free medium, they showed that the solvent-free conditions are better regardless of the nature of the starting materials. The green solvents are effective for alkyl and benzylamines, affording higher yields compared to arylamines. In all cases, the products are isolated with a high degree of purity, so purification by chromatography is not necessary. 


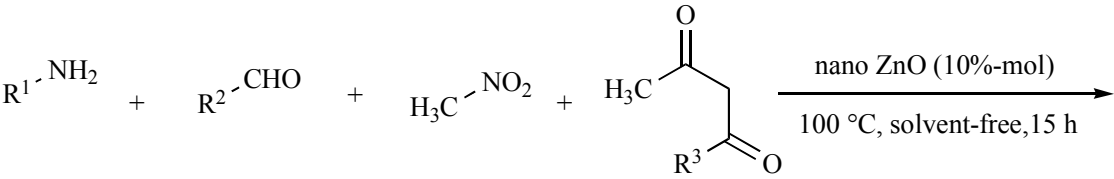

$$
\begin{aligned}
& \mathrm{R}^{1}=\mathrm{PhCH}_{2}, p-\mathrm{X}-\mathrm{Ph} \\
& \mathrm{X}=p-\mathrm{CH}_{3} \mathrm{O}, p-\mathrm{Br} \\
& \mathrm{R}^{2}=\mathrm{X}^{1}-\mathrm{Ph}, 2 \text {-furyl } \\
& \mathrm{X}^{1}=\mathrm{H}, p-\mathrm{Cl}, p-\mathrm{CH}_{3}, p=\mathrm{NO}_{2}, m-\mathrm{NO}_{2} \\
& \mathrm{R}^{3}=\mathrm{CH}_{3}, \mathrm{CH}_{3} \mathrm{CH}_{2} \mathrm{O}, \mathrm{CH}_{3} \mathrm{O}
\end{aligned}
$$

Scheme 22.

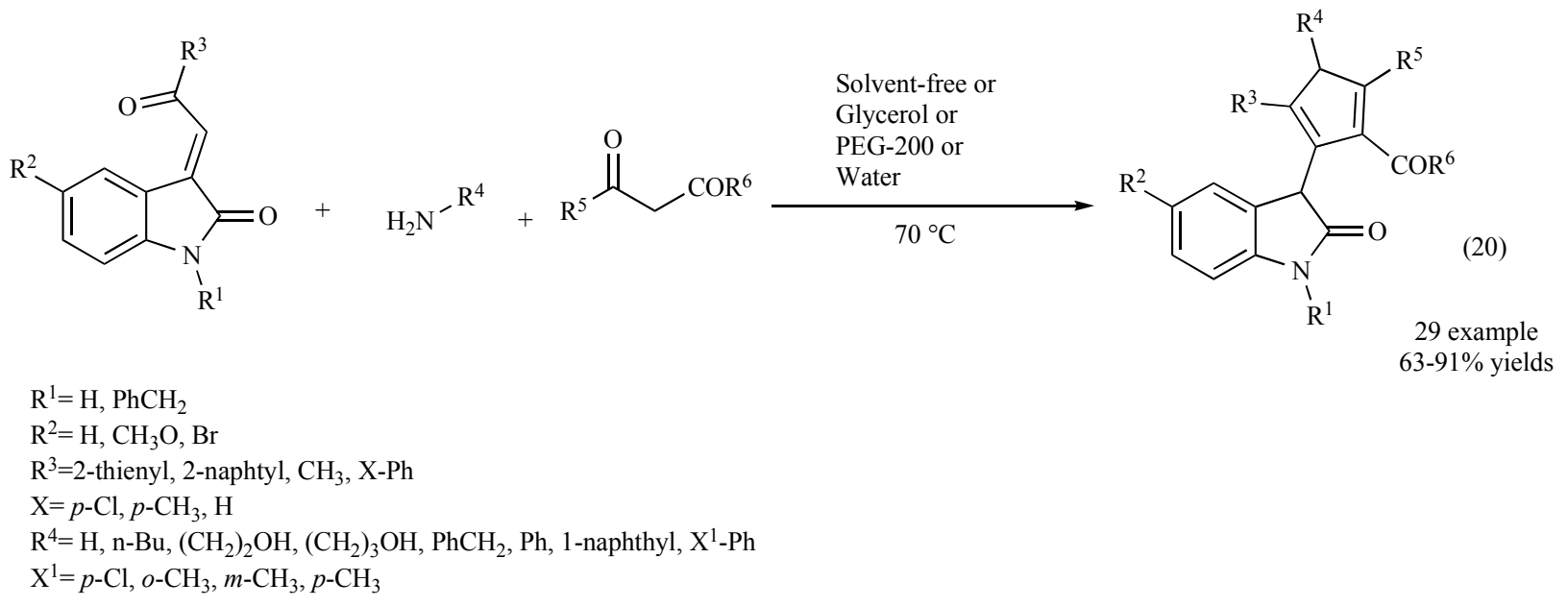

Scheme 23.

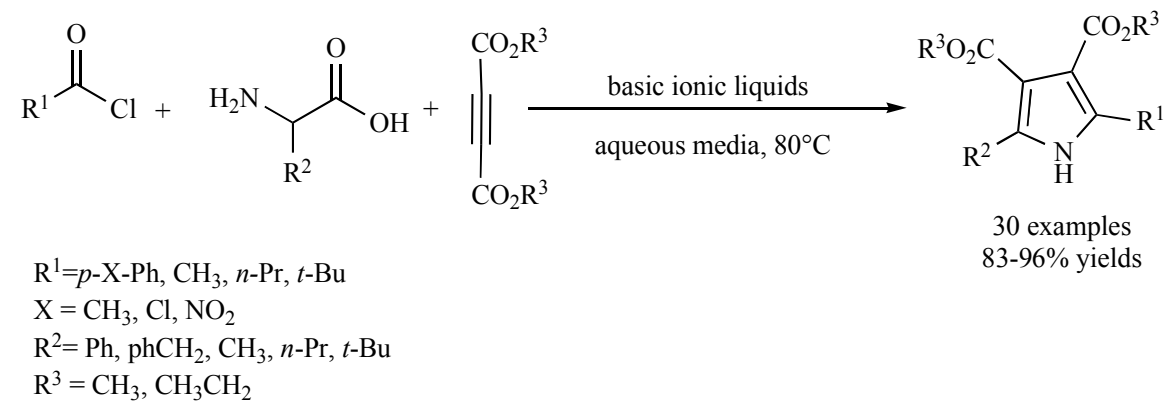

Scheme 24.

\subsubsection{Pyrrole Derivatives from Activated Alkynes}

Multicomponent reactions, such as the above-mentioned or the well-known Hantzsch reaction, have attracted great interest in recent years, especially those performed using activated alkynes bearing one or two carboxylate groups. A one-pot three-component synthesis was developed by Yavari et al. [65], using a basic ionic liquid as catalyst in aqueous medium (Scheme 24). The process is faster compared to catalysts such as sodium hydroxide and although it gives lower yields, the catalyst can be reused without significant loss of activity.

Another simple, fast and efficient methodology involving a three-component reaction was developed by Sabbaghan et al. [66], yielding polysubstituted pyrroles from amines, 2-bromoacetophenone and dialkyl acetylenedicarboxylates under solvent-free conditions, and $\mathrm{ZnO}$ nanostructures as catalyst (Scheme 25). Interestingly, the catalyst used is much cheaper than ionic liquids. The product affords between $75 \%$ and $94 \%$ yields, and the reaction times vary depending on the nature of the substrate. Aromatic amines do not produce the desired products, just like the reaction using bromopyruvate. The reusability of the catalyst was tested for the formation of diethyl 1-ethyl-5-phenyl-1H-pyrrole-2,3-dicarboxylate, which could be used up to three times without loss of catalytic activity after being recovered by filtration, washed with ethyl acetate and dried at room temperature for $24 \mathrm{~h}$ before each catalytic cycle.

Reaction media such as PEG-400 [67] have been used with good results for the same reaction, since it is a recyclable, biodegradable and inexpensive solvent. Although a structural variety similar to the one achieved using $\mathrm{NR}-\mathrm{ZnO}$ solvent-free medium is obtained, the reaction time increases to $10 \mathrm{~h}$ at a temperature of $60{ }^{\circ} \mathrm{C}$. However, all the reactions are very clean, and the yields for pyrrole derivatives are high. The use of 2-bromoacetophenones bearing electron-withdrawing substituents $\left(-\mathrm{Br},-\mathrm{NO}_{2}\right)$ in -para 


$$
\begin{aligned}
& \mathrm{R}^{1}=\mathrm{CH}_{3}\left(\mathrm{CH}_{2}\right)_{5}, \mathrm{CH}_{3} \mathrm{CH}_{2}, \mathrm{PhCH}_{2}, p-\mathrm{Cl}-\mathrm{PhCH}_{2}, p-\mathrm{CH}_{3}-\mathrm{PhCH}_{2}, \mathrm{Ph}, \mathrm{p}-\mathrm{CCH}_{3} \mathrm{O}-\mathrm{Ph} \\
& \mathrm{R}^{2}=\mathrm{CH}_{3}, \mathrm{CH}_{3} \mathrm{CH}_{2} \\
& \mathrm{R}^{3}=\mathrm{CH}_{3} \mathrm{O}_{2} \mathrm{Cl}
\end{aligned}
$$

Scheme 25.

$$
\begin{aligned}
& \begin{array}{l}
m-\mathrm{Cl}, m-\mathrm{CH} \\
,
\end{array} m-\mathrm{OH}, o-\mathrm{CH}_{3} \mathrm{CH}_{2} \\
& \mathrm{R}^{2}=\mathrm{CH}{ }_{2} \mathrm{CH}, \mathrm{CH} \\
& \mathrm{R}^{3}=\mathrm{Ph} \text {, thiophen-2-yl, } 4-\mathrm{CH}_{3} \mathrm{OC}_{6} \mathrm{H}_{4}, 4-\mathrm{CH}_{3} \mathrm{C}_{6} \mathrm{H}_{4}, 4-\mathrm{FC}_{6} \mathrm{H}_{4}, 4-\mathrm{ClC}_{6} \mathrm{H}_{4}
\end{aligned}
$$

Scheme 26.

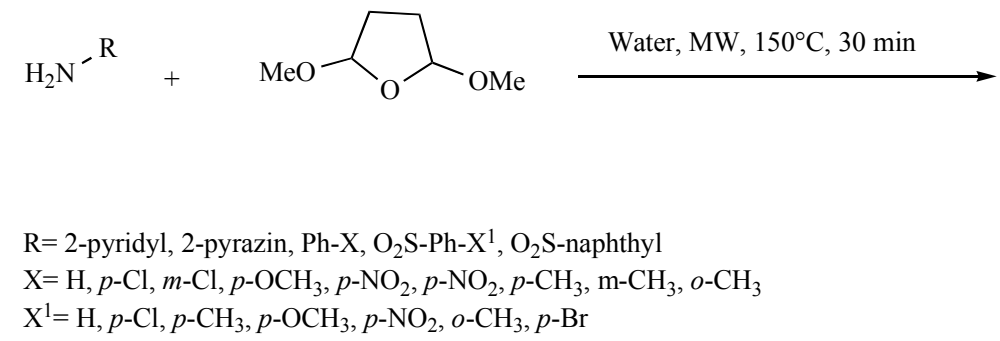

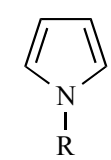

18 examples $81-99 \%$ yields
Scheme 27.

position, amines with electron-donating groups (-Me, -OMe) and electron-withdrawing groups $(-\mathrm{F})$ in -para position gave the desired products in high yields.

Not only three-component reactions have been developed for pyrrole derivative synthesis, Feng et al. [68] performed a fourcomponent synthesis using a mixture $(1: 1: 1: 1)$ of monohydrate arylglyoxal, aniline, dialkyl but-2-ynedioate or alkyl acetoacetate, and malononitrile in ethanol without catalyst (Scheme 26). Following this procedure, highly substituted pyrroles are obtained in excellent yields within $30 \mathrm{~min}$ with a low environmental impact as a green solvent is used in a reaction with high atom efficiency.

\subsubsection{Clauson-Kaas Reaction}

The Clauson-Kass reaction is a process of pyrrole synthesis based on the condensation between an aromatic or aliphatic primary amine with 2,5-dimethoxytetrahydrofuran in the presence of an acid catalyst. Generally, the acid catalysts used for the process are acetic acid, phosphorous pentoxide, and 4-chloropyridinium chloride. The reaction easily converts nitrogen of an amino group into a pyrrole group whenever there is not an acid labile group [19].

Wilson et al., in a catalyst-free medium and using water as solvent (principles 1, 3, 5, 7, 8 and 10 of Green Chemistry), were able to obtain $N$-aryl and $N$-arylsulfonylpyrroles [69] from 2,5- dimethoxytetrahydrofuran and various anilines and sulfonamides. The standard literature indicates good yields for these compounds using $\mathrm{P}_{2} \mathrm{O}_{5}$, a corrosive and extremely hygroscopic compound, and dry toluene as solvent, in times ranging from $45 \mathrm{~min}$ to $22 \mathrm{~h}$, which results in a complex matrix that requires a complicated series of purification steps [70]. In contrast with this report, in which the synthesis of these compounds is induced by MW and develops from different types of anilines and sulfonamides, these two compounds are easier to handle and with less risk of toxicity (Scheme 27), reaction times decrease to $30 \mathrm{~min}$, obtaining quantitative yields for some species (see Table 3). Furthermore, the study describes that the process depends on the $\mathrm{pK}_{\mathrm{a}}$ of the nucleophile used, so no acid catalysts are used.

A similar procedure using MW was developed by Miles et al. [71], promoting the reactions of less nucleophilic amines using acetic acid as reaction media, and the same catalyst reduced the reaction times to $10 \mathrm{~min}$ with high yields. It is noteworthy that despite the difficulties of using acetic acid as solvent, such as its volatility, it is a green and biodegradable solvent that comes from renewable sources. An interesting variation in the process was the release of the MW system and the use of catalysts and solvent-free conditions developed by Ramesh et al. [72] to synthesize $\mathrm{N}$ substituted pyrroles from aromatic amines. Again, as in the reactions listed above, the main drawback is the increased reaction time. 
Table 3. A comparison of experimental conditions for obtaining $\mathrm{N}$-aryl and $\mathrm{N}$-arylsulfonylpyrroles.

\begin{tabular}{|c|c|c|c|c|}
\hline Pyrrole & Reaction Conditions - Purification Methodology & $\begin{array}{c}\text { Yield } \\
(\%)\end{array}$ & Reaction Condition - Purification Methodology & $\begin{array}{c}\text { Yield } \\
(\%)\end{array}$ \\
\hline & $\begin{array}{c}\mathrm{P}_{2} \mathrm{O}_{5} \text {, dry toluene, } 125^{\circ} \mathrm{C}, 45 \text { min. Evaporation, flash } \\
\text { chromatography }\end{array}$ & 87 & Water, $\mathrm{MW}, 150^{\circ} \mathrm{C}, 30 \mathrm{~min}$, filtration & 90 \\
\hline & $\begin{array}{c}\mathrm{CuI}, n-\mathrm{Bu}_{4} \mathrm{NBr}, \mathrm{NaOH} \text {, toluene, reflux, } 22 \mathrm{~h} \text {. } \\
\text { Extraction, flash chromatography }\end{array}$ & 88 & Water, $\mathrm{MW}, 150^{\circ} \mathrm{C}, 30 \mathrm{~min}$, filtration & 98 \\
\hline & $\begin{array}{c}\mathrm{P}_{2} \mathrm{O}_{5} \text {, dry toluene, } 125^{\circ} \mathrm{C}, 45 \text { min, evaporation flash } \\
\text { chromatography }\end{array}$ & 79 & Water, $\mathrm{MW}, 150^{\circ} \mathrm{C}, 30 \mathrm{~min}$, filtration & 93 \\
\hline & $\begin{array}{c}\mathrm{CuI}, n-\mathrm{Bu}_{4} \mathrm{NBr}, \mathrm{NaOH} \text {, toluene, reflux, } 22 \mathrm{~h} . \\
\text { Extraction, flash chromatography }\end{array}$ & 84 & Water, $\mathrm{MW}, 150^{\circ} \mathrm{C}, 30 \mathrm{~min}$, filtration & 99 \\
\hline & $\begin{array}{l}\mathrm{CuI}, N \text {-hydroxymaleimide, } \mathrm{CH}_{3} \mathrm{ONa}, \mathrm{DMSO}, 110^{\circ} \mathrm{C}, 40 \\
\text { h. Extraction, flash chromatography }\end{array}$ & 45 & Water, $\mathrm{MW}, 150^{\circ} \mathrm{C}, 30 \mathrm{~min}$, filtration & 97 \\
\hline & $\begin{array}{l}\text { Montmorillonite K-10, } 3 \text { min MW. Filtration, flash } \\
\text { chromatography }\end{array}$ & 93 & Water, $\mathrm{MW}, 150^{\circ} \mathrm{C}, 30 \mathrm{~min}$, filtration & 99 \\
\hline $\begin{array}{l}\text { II } \\
\mathrm{O}\end{array}$ & $\begin{array}{c}\mathrm{P}_{2} \mathrm{O}_{5} \text {, dry toluene, } 125^{\circ} \mathrm{C}, 20 \text { min. Evaporation, flash } \\
\text { chromatography }\end{array}$ & 100 & Water, $\mathrm{MW}, 150^{\circ} \mathrm{C}, 30 \mathrm{~min}$, filtration & 89 \\
\hline II & $\begin{array}{c}\mathrm{P}_{2} \mathrm{O}_{5} \text {, dry toluene, } 125^{\circ} \mathrm{C}, 20 \text { min. Evaporation, flash } \\
\text { chromatography }\end{array}$ & 85 & Water, $\mathrm{MW}, 150^{\circ} \mathrm{C}, 30 \mathrm{~min}$, filtration & 92 \\
\hline $\mathrm{O}$ & $\begin{array}{l}\text { Montmorillonite K-10, } 3 \text { min MW. Filtration, flash } \\
\text { chromatography }\end{array}$ & 95 & Water, $\mathrm{MW}, 150^{\circ} \mathrm{C}, 30 \mathrm{~min}$, filtration & 95 \\
\hline & $\begin{array}{l}\mathrm{TfOH}, \mathrm{CH}_{2} \mathrm{Cl}_{2}, \mathrm{rt}, 2 \mathrm{~h} \text {. Extraction, flash } \\
\text { chromatography }\end{array}$ & 86 & Water, $\mathrm{MW}, 150^{\circ} \mathrm{C}, 30 \mathrm{~min}$, filtration & 98 \\
\hline
\end{tabular}

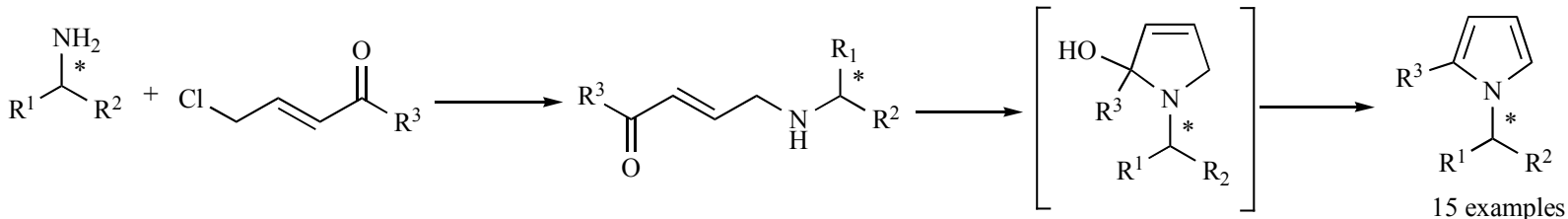

However, for deactivated anilines such as $p$-fluoro, $p$-chloro, $p$ bromo and $p$-nitroaniline, the reaction times are similar to that obtained with the unsubstituted aniline. In 2013, a series of pyrroles derived from chiral amines was obtained by this reaction in a solvent-free medium using an acidic ionic liquid, 1-hexyl-3methylimidazolium hydrogen sulfate $\left([\mathrm{hmim}]\left[\mathrm{HSO}_{4}\right]\right)$, as catalyst that, despite being a synthetic product, is considered a safe and environmentally friendly reagent [73]. Compared to acetic acid, $[\mathrm{hmim}]\left[\mathrm{BF}_{4}\right]$ and $[\mathrm{hmim}]\left[\mathrm{H}_{2} \mathrm{PO}_{4}\right]$, this compound increases by $30 \%$ the yield of the model reaction carried out between (S)phenylethylamine and 2,5-dimethoxytetrahydrofuran [74]. The process concludes with the use of MW $(90 \mathrm{~W})$, so that the processes are carried out for 4-25 min. However, the reusability of the catalyst is not mentioned.

\subsubsection{Pyrrole Derivatives from $\alpha$-aminoacids}

Because homochiral pyrroles derived from amine and amino acids are important starting reagents for the synthesis of various bio- logically active compounds, Demir et al. [75] developed a method for condensation synthesis from chiral amines, $\beta$-amino alcohols, and esters of $\alpha$-aminoacids with chloroenones (Scheme 28). The process results in yields above $60 \%$ without racemization of the products in mild reaction conditions (triethylamine reflux). Twelve compounds were obtained with enantiomeric excesses $\geq 98 \%$ in reaction times from 4 to $6 \mathrm{~h}$. The same working group developed a procedure using $\mathrm{MW}(500 \mathrm{~W})$, conducting the reaction in solid phase with silica gel as support and triethylamine as catalyst [76]. Thus, the reaction time was reduced to 4-6 min, with the advantages of good yields without racemization of the products and mild reaction conditions, avoiding toxic solvents and dangerous reagents.

\subsubsection{Pyrroles from Oximes and Carbide}

Calcium carbide is a major source of acetylene, an important raw material for the synthesis of various compounds via many reaction routes, such as carbonylation, dimerization, vinylation, ethinylation and oligomerization [77]. The oxime vinylation reaction allows obtaining 2-arylpyrroles, which are synthons for the synthesis 


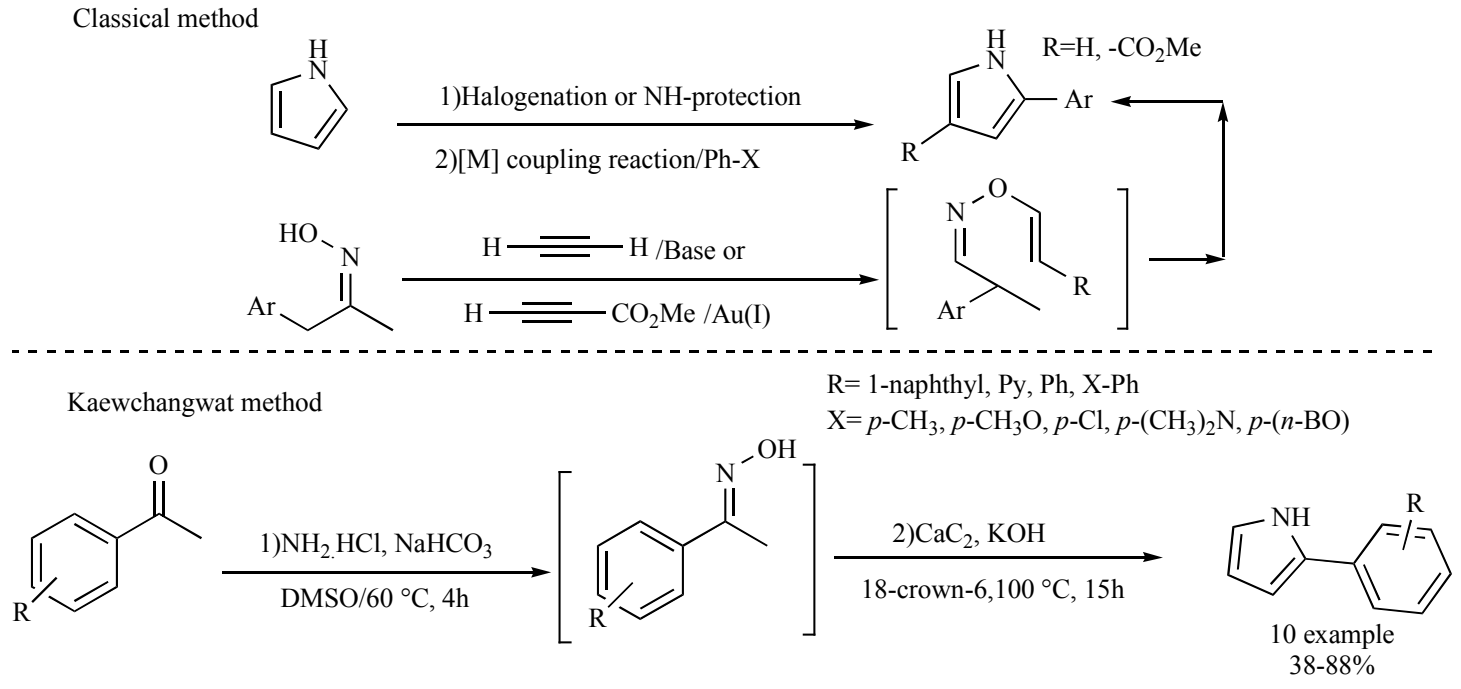

Scheme 29.

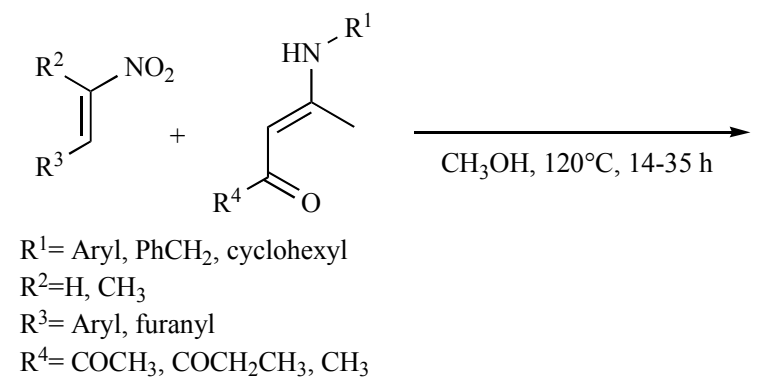

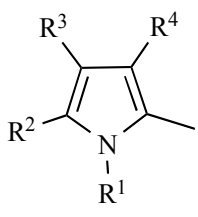

26 examples $54-92 \%$ yields

$\mathrm{R}^{4}=\mathrm{COCH}_{3}, \mathrm{COCH}_{2} \mathrm{CH}_{3}, \mathrm{CH}_{3}$

Scheme 30.

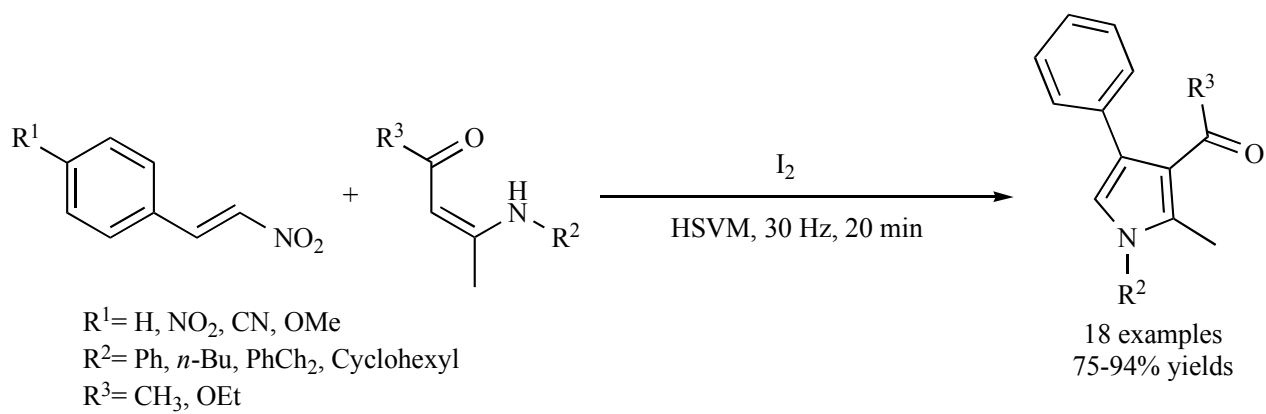

Scheme 31.

of BODIPY dyes. Kaewchangwat's group [78] developed a one-pot simple procedure starting from acetophenones and hydroxylamine for obtaining oximes that are converted into 2 -arylpyrroles by reaction with $\mathrm{CaC}_{2}$ in a similar reaction to that of Trofimov process, but avoiding the use of heavy metals as catalysts (Scheme 29). The process uses DMSO as reaction solvent for the hydrolysis of $\mathrm{CaC}_{2}$ to generate acetylene in situ. The reaction is performed in basic medium using potassium hydroxide and 18-crown-6 as catalyst, with process yields ranging from $38 \%$ to $88 \%$ at $100{ }^{\circ} \mathrm{C}$. The method developed uses inexpensive starting materials (ketoximes), avoids handling acetylene gas and heavy metals, and the general steps of the process are significantly shortened. Therefore, it can be considered a convenient, safe, environmentally friendly, green and sustainable process. Moreover, it can be easily applied in large scale manufacturing in chemical industries and for routine laboratory synthesis.

\subsubsection{Pyrroles from Nitroolefins}

The metal-free synthesis of substituted pyrroles by domino reaction with cyclic enaminones and halogenated nitroolefins has been reported. However, this procedure is not environmentally friendly due to the use of halogenated compounds [79]. Michael addition and cyclization of enaminones or enaminoesters to nitroolefins is a straightforward approach to the construction of the pyrrole rings according to the principles of Green Chemistry (Scheme 30). Guan et al. [80] improved the synthetic method and developed an efficient, practical and environmentally friendly method for the synthesis of polysubstituted pyrroles. Under optimized reaction conditions, they studied the effect of substrates, starting from the reaction of 1- (2-nitroprop-1-enyl) benzene, several enaminoesters and methyl-3-(phenylamino) but-2-enoate with several nitroolefins. This process has a high tolerance to a wide variety of functional groups. Nitroolefins with methyl, methoxy, amino, fluoro and chloro groups in the aromatic ring produce the corresponding pyrroles in good yields. In general, the electron-rich nitroolefins are more reactive than electron-deficient ones. Electron-rich enaminoesters show increased reactivity and give higher yields than electron-deficient ones; however, reactions are insensitive to steric hindrance of the substituents on aromatic rings. The reaction was improved by Gao's group [81] by applying HSVM 
using molecular iodine as catalyst in a solvent-free medium. The optimized methodology is performed at $30 \mathrm{~Hz}$, reducing the reaction time to $20 \mathrm{~min}$, the polysubstituted pyrroles reaching between $78 \%$ and $94 \%$ yields (Scheme 31 ).

\section{CONCLUSION}

The main challenge of Green Chemistry is to gradually eliminate the generation of hazardous or harmful materials or replace them with less toxic and safer ones. However, this process must be driven by scientific developments. Its application in the synthesis of heterocyclic compounds such as pyrrole derivatives involves multiple economic and social benefits due to the biological importance of these compounds and their direct impact on the pharmaceutical industry. Although many processes using novel methodologies of green activation, such as microwaves, ultrasound and HSVM, as well as synthetic processes in continuous flow and processes at room temperature are still under investigation, promising results such as cost and waste reduction and greater efficiency are achieved.

\section{CONFLICT OF INTEREST}

The authors confirm that this article content has no conflict of interest.

\section{ACKNOWLEDGEMENTS}

This work was funded by Universidad Nacional de La Plata, CONICET (PIP 003). ANPCyT (PICT 0409). AGS and GPR are members of CONICET.

\section{REFERENCES}

[1] Harreus, A.L. In: Ullman's encyclopedia of industrial chemistry; WileyVCH Verlag GmbH \& Co. KGaA: Weinheim, 2000; Vol. 30, pp.615-618.

[2] Majumdar K.C.; Chattopadhyay S.K. In: Pyrrole and Its Derivatives, in Heterocycles in Natural Product Synthesis; K. C. Majumdar and S. K. Chattopadhyay, Eds.; Wiley-VCH Verlag GmbH \& Co. KGaA: Weinheim, 2011; Vol.1, pp. 187-220.

[3] Teixeira, C.; Barbault, F.; Rebehmed, J.; Liu, K.; Xie, L.; Lu, H.; Jiang, S.; Fan, B.; Maurel, F. Molecular modeling studies of N-substituted pyrrole derivatives-Potential HIV-1 gp41 inhibitors, Bioorg. Med. Chem., 2008, 16, 3039-3048.

[4] Bhardwaj, V.; Gumber, D.; Abbot, V.; Dhiman, S.; Sharma, P. Pyrrole: A resourceful small molecule in key medicinal hetero-aromatics, $R S C A d v$., 2015, 5, 15233-15266.

[5] Wurz, R. P.; Charette, A. B. Doubly Activated Cyclopropanes as Synthetic Precursors for the Preparation of 4-Nitro- and 4-Cyano-dihydropyrroles and Pyrroles, Org. Lett., 2005, 7(12), 2313-2316.

[6] Li, J.J. Heterocyclic chemistry in drug discovery, 1st Ed.; Jhon Wiley \& Sons: New York, 2013

[7] Cheon, K. H.; Cho, J.; Kim, Y.; Chung, D.S. Thin film transistor gas sensors incorporating high mobility diketopyrrolopyrole-based polymeric semiconductor doped with graphene oxide, ACS Appl. Mater. Interfaces, 2015, 7(25), 14004-14010.

[8] Yao, T.; Wang, C.; Wu, J.; Lin, Q.; Lv, H.; Zhang, K.; Yu, K.; Yang, B. Preparation of raspberry-like polypirrole composites with applications in Catalysis, J. Colloid Interface Sci., 2009, 338(2), 573-577.

[9] Krim, O.; Bouachrine, M.; Hammouti, B.; Elidirissi, A. Hamidi, M. 2,5Difuryl-N-methylpyrrole as corrosion inhibitor for Steel in $1 \mathrm{M} \mathrm{HCl}$, Portugaliae Electrochimica Acta, 2008, 26, 283-289.

[10] Ash, M.; Ash, I. Handbook of preservatives, 1st. Ed.; Synapse information resources, Inc.: Stamford, 2004

[11] Wong, H.; Ko, C.; Lam, W.; Zhu, N.;Wing-Wah, V. Design and synthesis of new class of photochromic diarylethene-containing dithieno[3,2b:2',3'd]pyrroles and their switchable luminescence properties, Chem. Eur. J., 2009, 39(15), 10005-10009.

[12] Bhatt, K. D.; Vyas, D. J.; Makwana, B.A.; Darjee, S.M.; Jain, V.K. Highly stable water dispersable calix[4]pyrroleocta-hydrazide protected gold nanoparticles as colorimetric and fluorometric chemosensors for selective signaling of Co(II) ions, Spectrochim. Acta, Part A, 2014, 121, 94-100.

[13] Balme, G., Pyrrole synthesis by multicomponent coupling reactions, Angew. Chem. Int. Ed., 2004, 46(43), 6238-6241.

[14] Li, J.J. Name Reactions, 4 th Ed.; Springer Berlín Heidelberg: Berlín, 2009.

[15] Akbaslar, D.; Demirkol, O.; Giray, S. Paal-Knorr Pyrrole synthesis in water, Synth. Comm., 2014, 44, 1323-1332.
[16] Wang, S.F ; Guo, C.L. Cui, K.K ; Zhu, Y T ; Ding, J.X · Zou, X.Y · Li, Y.H., Lactid acid as an invaluable Green solvent for ultrasound-assisted scalable synthesis of pyrrole derivatives, Ultrason. Sonochem., 2015, 26, 81-86.

[17] Vivekanand, T.; Vinoth, P.; Agieshkumar, B.; Sampath, N.;Sudalai, A.;Menéndez, J.C.;Sridharan, V., Highly efficient regioselective synthesis of pyrroles via a tandem enamine formation - Michael addition- cyclization sequence under catalyst- and solvent-free conditions, Green Chem., 2015, 17, 3415-3423.

[18] Wang, Z. Comprehensive Organic Name Reactions and Reagents; John Wiley \& Sons: New York, 2009.

[19] Kürti, L.; Czakó, B. Strategic Applications of named reactions in organic synthesis, 1st Ed.; Elsevier: San Diego, 2005.

[20] Manley, J.M.; Kalman, M.J.; Conway, B.G.; Ball, C.C.; Havens, J.L.; Vaidyanathan, R., Early amidation approach to 3-[(4-amido)pyrrol-2-yl]-2 indolinones, J. Org. Chem., 2003, 16 (68), 6447-6450.

[21] Alberola, A.; Gonzáles, A.; Sádaba, M.L.; Sañudo, C., Versatility of Weinreb amides in the Knorr pyrrole synthesis, Tetrahedron, 1999, 21(55), 65556556

Wang, S.F.; Guo, C.L.; Cui, K.K.; Zhu, Y.T.; Ding, J.X.; Zou, X.Y.; Li, Y.H., Lactic acid as an invaluable green solvent for ultrasound-assisted scalable of pyrrole derivatives, Ultrason. Sonochem., 2015, 26, 81-86.

[23] Brummond, K.M.; Curran, D.P.; Mitasev, B.; Fischer, S., Heterocyclic $\alpha-$ alkylidene cyclopentenones obtained via a Pauson-Khand reaction of amino acid derived allenynes. A Scope and limitation study directed toward the preparation of a tricyclic pyrrole library, J. Org. Chem., 2005, 5(70), 1745 1753

[24] Vekariya, R.H.; Patel, H.D., Sulfonated polyethyleneglycol (PEG-OSO3H) as a polymer supported biodegradable and recyclable catalyst in green organic synthesis: recent advances, $R S C A d v$., 2015, DOI: $10.1039 / \mathrm{c} 5 \mathrm{ra} 06532 \mathrm{a}$.

[25] Wang, B.; Gu, Y.; Luo, C.; Yang, T.; Yang, L.; Suo, J., Pyrrole synthesis in ionic liquids by Paal-Knorr condensation under mild conditions, Tetrahedron Lett., 2004, 17(45), 3417-3419.

[26] Sharma, A.; Piplani, P., Microwave-activated synthesis of pyrroles: A shor review, J. Heterocyclic Chem., 2015, doi:10.1002/jhet.2550.

[27] Zhang, Z.H.; Li, J.J.; Li, T.S., Ultrasound-assisted synthesis of pyrroles catalyzed by zirconium chloride under solvent-free conditions, Ultrason. Sonochem., 2008, 5(15), 673-676.

[28] Minetto, G.; Raveglia, L.F.; Sega, A.; Taddei, M., Microwave-assisted PaalKnorr reaction-three-step regiocontrolled synthesis of polysupstituted furans, pyrroles and thiophenes, Eur. J. Org. Chem., 2005, 24 (2005), 5277-5288.

[29] Akelis, L.; Rousseau, J.; Juskenas, R.; Dodonova, J.; Rousseau, C.; Menuel, S.; Prevost, D.; Tumkevicius, S.; Monflier, E.; Hapiot, F., Greener PaalKnorr pyrrole synthesis by mechanical activation, Eur. J. Org. Chem., 2016, 1(2016), 31-35.

[30] Curini, M.; Montanari, F.; Rosati, O ; Lioy, E.; Margarita, R., Layered zirconium phosphate and phosphonate as heterogeneous catalyst in the preparation of pyrroles, Tetrahedron Lett., 2003, 20(44), 3923-3925.

[31] Banik, B.K.; Banik, I.; Renteria, M.; Dasgupta, S.K., A straightforward highly efficient Paal-Knorr synthesis of pyrroles, Tetrahedron Lett., 2005 , 15(46), 2643-2645

[32] Chen, J.; Wu, H.; Zheng, Z.; Jin, C.; Zhang, X.; Su, W., An approach to the Paal-Knorr pyrroles synthesis catalyzed by $\mathrm{Sc}(\mathrm{OTf}) 3$ under solvent-free conditions, Tetrahedron Lett., 2006, 30(47), 5383-5387.

[33] De, S.K., Sulfamic acid as a novel, efficient, cost-effective, and reusable solid acid catalyst for the synthesis of pyrroles under solvent-free conditions, Synth. Commun., 2008, 5(38), 803-809.

[34] Narayanaswamy Venugopala, K.; Prasanna, R.T.; Odhav, B., Trifluoroacetic acid: An efficient catalyst for Paal-Knorr pyrrole synthesis and its deprotection, Asian J. Chem., 2013, 15(25), 8685-8689.

[35] Karami, B.; Khodabakhshi, S.; Jamshidi, M., Green and rapid strategy for the synthesis of novel and known pyrroles by the use of molybdate sulfuric acid, J. Chin. Chem. Soc., 2013, 9(60), 1103-1106.

[36] Song, G.; Wang, B.; Wang, G.; Kang, Y.; Yang, T.; Yang, L., Fe3+montomorillonite as effective, recyclable catalyst for Paal-Knorr pyrrole synthesis under mild conditions, Synth. Commun., 2005, 8(35), 1051-1057.

[37] Devi, A.; Shallu; Sharma, M.L.; Singh, J., Paal-Knorr pyrrole synthesis using recyclable amberlite IR 120 acidic resin: A green approach, Synth. Commun., 2012, 10(42), 1480-1488

[38] Karami, B.; Jamshidi, M.; Khodabakhshi, S., Modified Paal-Knorr synthesis of novel and known pyrroles using tungstate sulfuric acid as a recyclable catalyst, Lett. Org. Chem., 2013, 10(13), 12-16.

[39] Cheraghi, S.; Saberi, D.; Heydari, A., Nanomagnetically modifies sulfuric acid $(\gamma$-Fe2O3@SiO2-OSO3H): An efficient, fast, and reusable catalyst for greener Paal-Knorr pyrrole synthesis, Catal. Lett., 2014, 7(144), 1339-1343.

[40] Rahmatpour, A., Xanthan sulfuric acid as an efficient, green, biodegradable, and recyclable solid acid catalyst for one-pot synthesis of N-substituted pyrroles under solvent-free conditions at room temperature, Monatsh. Chem., 2012, 3(143), 491-495.

[41] Jafari, A.A.; Amini, S.; Tamaddon, F., A green, chemoselective, and efficient protocol for Paal-Knorr pyrrole and Bispyrrole synthesis using biodegradable polymeric catalyst PEG-SO3H in water, J. Appl. Polym. Sci., 2012, 2(125), $1339-1345$. 
[42] Banik, M.; Ramírez, B.; Reddy, A.; Banyopadhyay, D.; Banik, B.K., Polyestyrenesulfonate-catalyzed synthesis of novel pyrroles through Paal-Knorr reaction, Org. Med. Chem. Lett., 2012, 2(2012), 11-15.

[43] Bhandari, N.; Gaonkar, S.L., A facile synthesis of N-Substituted 2,5dimethylpyrroles with saccharin as a green catalyst, Chem. Heterocycl. Compd., 2015, 4(51), 320-323.

[44] Duan, F. J.; Ding, J.C.; Deng, H.J.; Chen, D.B ; Chen, J.X. Liu, M.C.; Wu, H.Y., An approach to the Paal-Knorr pyrroles synthesis in the presence of $\beta$ cyclodextrin in aqueous media, Chin. Chem. Lett., 2013, 9(24), 793-796.

[45] Wang, B.; Gu, Y.; Luo, C.; Yang, T.; Yang, L.; Suo, J, Pyrrole synthesis in ionic liquids by Paal-Knorr condensation under mild conditions, Tetrahdron Lett., 2004, 17(45), 3417-3419.

[46] Akbaslar, D.; Demirkol, O.; Giray, S., Paal-Knorr pyrrole synthesis in water, Synth. Commun., 2014, 9(44), 1323-1332.

[47] Cho, H.; Madden, R.; Nisanci, B.; Török, B., The Paal-Knorr reaction revisited. A catalyst and solvent-free synthesis of underivatized and $\mathrm{N}$-substituted pyrroles, Green Chem., 2015, 2(17), 1088-1099.

[48] Anastas, P. T.; Warner, J. C. Green Chemistry: Theory and Practice, Oxford University Press: New York, 1998, p. 30

[49] Roomi, M.W.; MacDonald, S.F., The Hantzsch pyrrole synthesis, Can. J. Chem., 1970, 48, 1689 - 1697.

[50] Estévez, V.; Villacampa, M.; Menéndez, J.C., Multicomponent reactions for the synthesis of pyrroles, Chem. Soc. Rev., 2010, 39, 4402-4421.

[51] Trautwein, A.W.; Sübmuth, R.D.; Jung, G., Hantzsch pyrrole synthesis on solid support, Bioorg. Med. Chem. Lett., 1998, 8, 2381-2384.

[52] Trautwein, A.W.; Jung, G., Solid-phase synthesis of pyrroles from enaminones and nitroalkenes, Tetrahedron Lett., 1998, 39, 8263-8266.

[53] Herath, A.; Cosford, N.D.P., One-step continuous flow synthesis of highly substituted pyrrole-3-carboxylic acid derivatives via in situ hydrolysis of tertbutyl esters, Org. Lett., 2010, 22(12), 5182-5185.

[54] Jas, G.; Kirschning, A., Continuous flow techniques in organic synthesis, Chem. Eur. J., 2003, 23(9), 5708-5723.

[55] Pashkova, A.; Greiner, L., Towards small-scale continuous Chemical production: Technology gaps and challenges, Chem. Ing. Tech., 2011, 83(9), 1337-1342.

[56] Estévez, V.; Villacampa, M.; Menéndez, C., Recent advances in the synthesis of pyrroles by multicomponent reactions, Chem. Soc. Rev., 2014, 43(13), 4633-4657.

[57] Murthy, S.N.; Madhav, B.; Kumar, A.V.; Rao, K.R.; Nageswar, Y.V.D., Multicomponent approach towards the synthesis of substituted pyrroles under supramolecular catalysis using $\beta$-cyclodextrin as a catalyst in water under neutral conditions, Helv. Chim. Acta, 2009, 10 (92), 2118-2124.

[58] Moss, T.A.; Nowak, T., Synthesis of 2,3-dicarbonylated pyrroles and furans via the three-component Hantzsch reaction, Tetrahedron Lett., 2012, 24(53), 3056-3060.

[59] Eftekhari-Sis, B; Vahdati-Khajeh, S., Ultrasound-assisted Green synthesis of pyrroles and pyridazines in water via three-component condensation reactions of arylglyoxals, Curr. Chem. Lett., 2013, 2, 85-92.

[60] Estévez, V.; Villacampa, M.; Menéndez, J.C., three-component access to pyrroles promoted by the CAN-Silver nitrate system under high-speed vibration milling conditions: a generalization of the Hantzsch pyrrole synthesis, Chem. Commun., 2013, 49, 591-593.

[61] Estévez, V.; Villacampa, M.; Menéndez, C., Concise synthesis of atorvastatine lactone under high-speed vibration milling conditions, Org. Chem. Front., 2014, 5(1), 458-463.

[62] Estévez, V.; Sridharan, V.; Sabaté, S.; Villacampa, M.; Menéndez, J.C., Three-component synthesis of pyrrole-related nitrogen heterocycles via a Hantzsch-type process: Comparison between conventional and high-speed vibration milling conditions, Asian J. Org. Chem., 2016, doi: 10.1002/ajoc.201600061
[63] Domling, A. Ugi, I, Multicomponent reactions with isocyanides, Angew. Chem. Ind. Ed., 2000, 18(39), 3168-3210.

[64] Matloubi Moghaddam, F.; Mirjafary, Z.; Motamen, S.; Jebeli Javan, M., Efficient synthesis of highly substituted pyrroles via a multi-component reaction using $\mathrm{ZnO}$ nanoparticles as a nanocatalyst, Sci. Iran., 2015, 3(22), 948953.

[65] Yavari, I. Kowsari, E.; Efficient and green synthesis of tetrasubstituted pyrroles promoted by task-specific basic ionic liquids as catalyst in aqueous media, Mol. Divers., 2009, 4(13), 519-528.

[66] Sabbaghan, M.; Ghalaei, A., Catalyst application of $\mathrm{ZnO}$ nanostructures in solvent free synthesis of polysubstituted pyrroles, J. Mol. Liq., 2014, 193 , 116-122.

[67] Nagarapu, L.; Mallepalli, R.; Yeramanchi, L.; Bantu, R., Polyethylene glycol (PEG-400) as an efficient and recyclable reaction medium for one-pot synthesis of polysubstituted pyrroles under catalyst-free conditions, Tetrahedron Lett., 2011, 26(52), 3401-3404.

[68] Feng, X.; Wang, Q.; Lin, W.; Dou, G.L.; Huang, Z.B.; Shi, D.Q., Highly efficient synthesis of polysubstituted pyrroles via four component domino reaction, Org. Lett., 2013, 10(15), 2542-2545.

[69] Wilson, M.A.; Filzen, G.; Welmaker, G.S., A microwave-assisted, green procedure for the synthesis of $\mathrm{N}$-arylsulfonyl and $\mathrm{N}$-aryl pyrroles, Tetrahedron Lett., 2009, 34 (50), 4807-4809.

[70] Fang, Y.; Leysen, D.; Ottenheijm, H.C.J., A facile synthesis of N-substituted pyrroles, Synth. Commun., 1995, 12 (25), 1857- 1861.

[71] Miles, K.C.; Mays, S.M.; Southerland, B.K.; Auvill, T.J.; Ketcha, D.M.; The Clauson-Kass pyrroles synthesis under microwave irradiation, ARKIVOC, 2009, 14, 181-190.

[72] Ramesh, K.; Murthy, S.N.; Nageswar, Y. V. D., Synthesis of N-Substituted pyrroles under catalyst- and solvent-free conditions, Synth. Commun, 2012, 16 (42), 2471-2477.

[73] Fraga-Dubreuil, J.; Bourahla, K.; Rahmouni, M.; Bazureau, J.P.; Hamelin, J. Catalysed esterifications in room temperature ionic liquids with acidic counteranion as recyclable reaction media, Catal. Commun., 2002, 5(3), 185-190.

[74] Aydogan, F.; Yolacan, C., Clauson Kaas pyrrole synthesis catalyzed by acidic ionic liquid under microwave irradiation, Journal of Chemistry, $\mathbf{2 0 1 3}$ Article ID 976724, 6 pages, doi:10.1155/2013/976724.

[75] Demir, A.S.; Akhmedov, I.M.; Tanyeli, C.; Gercek, Z.; Gadzhili, R.A., Conversion of homochiral amines, $\beta$-aminoalcohols and $\alpha$-amino acids to their chiral 2-methylpyrrole derivatives, Tetrahedron Asymm., 1997, 5(8), 753-757.

[76] Aydogan, F.; Demir, A.S.; Clean and efficient microwave-solvent-free conversion of homochiral amines, $\alpha$-amino alcohols and $\alpha$-aminoacids to their chiral 2-substituted pyrrole derivatives, Tetrahedron, 2005, 12(61), 3019-3023.

[77] Rodygin, K.S.; Werner, G.; Kucherov, F.A.; Ananikov, V.P., Calcium carbide: A unique reagent for organic synthesis and nanotechnology, Chem. Asian J., 2016, 7(11), 965-976.

[78] Kaewchangwat, N.; Sukato, R.; Vchirawongkwin, V.; Vilaivan, T.; Sukwattanasinitt, M.; Wacharasindhu, S., Direct synthesis of aryl substituted pyrroles from calcium carbide: an underestimated Chemical feedstock, Green Chem., 2015, 1(17), 460-465.

[79] Rueping, M; Parra, A., Fast, efficient, mild, and metal-free synthesis of pyrroles by domino reactions in water, Org. Lett., 2010, 22(12), 5281-5283.

[80] Guan, Z.H.; Li, L.; Ren, Z.H.; Li, J.; Zhao, M.N, A facile and efficient synthesis of multisubstituted pyrroles from enaminoesters and nitroolefins, Green Chem., 2011, 7(13), 1664-1668.

[81] Xu, H.; Li, Y.; Xing, M.; Jia, J.; Han, L.; Ye, Q.; Gao, J., Synthesis of pyrroles from $\beta$-enamines and nitroolefins catalyzed by $\mathrm{I}_{2}$ under High-speed vibration milling (HSVM), Chem. Lett., 2015, 4(44), 574-576. 